\title{
Effects of geodynamic setting on the redox state of fluids released by subducted mantle lithosphere
}

\author{
K.A. Evans ${ }^{\mathrm{a}}$, S.M. Reddy ${ }^{\mathrm{a}}$, A.G. Tomkins ${ }^{\mathrm{b}}$, R.J. Crossley ${ }^{\mathrm{a}}$, B.R. Frost ${ }^{\mathrm{c}}$ \\ ${ }^{a}$ Dept. Applied Geology, Curtin University, GPO Box U1987, Bentley, WA 6845, \\ Australia \\ ${ }^{b}$ School of Earth, Atmosphere and Environment, Monash University, Melbourne, \\ Victoria 3800, Australia \\ ${ }^{c}$ University of Wyoming, Laramie, USA
}

\section{Abstract}

Magnetite breakdown during subduction of serpentinised ultramafic rocks may produce oxidised fluids that oxidise the deep Earth and/or the subarc mantle, either via direct transport of ferric iron, or via redox reactions between ferric iron and other elements, such as sulfur. However, so far, there is no consensus on the oxidation state of fluids released during subduction of ultramafic rocks, or the factors that control this oxidation state.

Subducted samples from a magma-poor rifted margin and a supra-subduction zone geodynamic setting were compared to examine evidence of changes in opaque phase assemblage and ferric iron content as a consequence of subduction, and as a function of geodynamic setting. Thermodynamic calculations in the system Fe-Ni-O-H-S and Fe-Ni-O-S at the pressures and temperatures of interest were used to constrain oxygen activities and fluid compositions.

Samples from New Caledonia, which exemplify supra-subduction zone mantle, contain awaruite $\left(\mathrm{FeNi}_{3}\right)$ and equilibrated with hydrogen-bearing flu-

Email address: k.evans@curtin.edu.au (K.A. Evans ) 
ids at oxygen activity less than the FMQ (fayalite-magnetite-quartz) buffer. In contrast, samples from the Zermatt Saas Zone ophiolite, Western Alps, which are thought to represent mantle from a subducted magma-poor rifted margin, contain magnetite plus sulfur-rich phases such as pyrite $\left(\mathrm{FeS}_{2}\right)$, and are inferred to have equilibrated with hydrogen-poor fluids at oxygen activity greater than FMQ. This major difference is independent of differences in subduction pressure-temperature conditions, variation in peridotite protolith composition, or the nature of adjacent units. We propose that the Zermatt Saas Zone samples would have undergone more complete serpentinisation prior to subduction than the supra-subduction zone (SSZ) New Caledonian samples. This difference explains the different fluid compositions, because incompletely serpentinised rocks containing olivine and brucite retain or evolve awaruite-bearing assemblages that buffer fluid compositions to high hydrogen activity $\left(a \mathrm{H}_{2}\right)$.

Ultramafic rocks are associated with two distinctly different fluid compositions during pre-subduction and subduction serpentinisation. Initially, while olivine is in equilibrium with infiltrating fluid, mineral assemblages that include awaruite in the rocks buffer fluids to $\mathrm{H}_{2}$-bearing, low $a \mathrm{O}_{2}$ compositions. Deserpentinisation of incompletely serpentinised rocks in which awaruite is present also produces $\mathrm{H}_{2}$-bearing fluids. Once awaruite is exhausted, $\mathrm{H}_{2}$-poor, high $a \mathrm{O}_{2}$ fluids co-exist with awaruite-absent assemblages, and deserpentinisation of such rocks would produce $\mathrm{H}_{2} \mathrm{O}$-rich fluids.

Thus, deserpentinisation of ultramafic rocks could produce either hydrogenbearing fluids that could infiltrate and reduce the sub-arc mantle, or more oxidised fluids, which could transfer redox budget to other geochemical reser- 
voirs such as the sub-arc mantle. Therefore, the redox contribution of subducted ultramafic rocks to the deep Earth and sub-arc mantle depends on the extent of protolith serpentinisation. Pre-subduction settings that promote extensive serpentisation by oxidised fluids at high fluid:rock ratios in open systems, such as slow and ultraslow spreading ridges, transform faults, oceanic core complexes, and exhumed mantle at rifted continental margins, may produce more oxidised fluids than those associated with less pervasive serpentinisation and fluids that may be rock-buffered to a reduced state.

Keywords: redox, subduction, ultramafic, awaruite, sulfur, iron

\section{Introduction}

The oxidation state of sub-arc mantle is a first order control on the composition and metal-carrying capacity of arc-derived magmas (Mungall, 2002). However, geochemical proxies for sub-arc mantle oxidation state in

5 arc magma samples produce inconsistent results (Lee et al., 2005; Kelley and Cottrell, 2009; Mallmann and O'Neill, 2009; Evans et al., 2012b; Parkinson and Arculus, 1999). Changes in the concentrations of redox sensitive elements in subducted material record the redox state of fluids released from these rocks, and provide an alternative way to assess the potential of subduction to modify sub-arc mantle oxidation state via changes to its redox budget. Redox budget is a quantitative compositional measure of the oxidizing capacity of a material (Evans, 2006), such that an increase in redox budget indicates an increase in the concentration of elements oxidised relative to the same elements in a reference state material. 
tinisation (Oufi et al., 2002; Evans, 2008; Klein et al., 2009, Andreani et al., 2013; Frost et al., 2013), and therefore holds significant redox budget. It is possible that this lithology is the largest contributor of redox budget to subduction zones (Evans, 2012). However, the effects of subduction on opaque phases, such as magnetite, in ultramafic rocks are almost unknown. Recently, attempts have been made to address this issue. Debret et al. (2014a) record decreases in magnetite modes and in the ferric iron content of serpentine with increasing pressure in high pressure - low temperature (HPLT) rocks, and use these results to infer that the redox budget of subducted mantle lithosphere decreases as pressure increases, and that this decrease in redox budget records the loss of oxidised fluids.

The observations of Debret et al. (2014a) are consistent with records from iron isotopes, which have been interpreted to record loss of $\mathrm{SO}_{2}$-bearing $\mathrm{flu}$ ids from serpentinites during subduction (Debret et al., 2016). In contrast, Peretti et al. (1992) use observations of hydrogen-rich fluid inclusions in HPLT rocks from Val Malenco in the Western Alps, to infer that fluids released by subducted mantle are hydrogen-rich and reducing. Loss of such a hydrogen-rich fluid would act to increase the redox budget of the residual subducted mantle lithosphere, and decrease the redox budget of the lithologies that it infiltrated. The results of Peretti are consistent with preliminary results from thermodynamic models that predict loss of methane and $\mathrm{H}_{2} \mathrm{~S}$ during prograde HPLT metamorphism (Evans and Powell, 2015).

There are a number of possible reasons for these apparently contradictory observations. Studies of exhumed mantle lithosphere involve a range 40 of possible protoliths that include, but are not limited to, variably serpen- 
tinised abyssal peridotites from ridge environments, supra subduction zone (SSZ) mantle, serpentinised peridotite from oceanic core complexes, and subcontinental lithospheric mantle exposed at rifted margins. Samples from different geodynamic settings are likely to have undergone different styles of fluid-rock interaction prior to subduction, so that the pre-subduction protolith may have differing extents of serpentinisation and metasomatic alteration. Thus it is necessary to consider the role of the geodynamic setting of the ultramafic protolith in the evolution of serpentinite-derived redox budget, and the implications for the evolving redox budget of the sub-arc mantle and deep Earth.

Inputs from units adjacent to lithospheric mantle may also contribute to the evolution of redox budget during metamorphism. For example, sedimentary units in the subducting slab evolve fluids that infiltrate, interact with, and drive metamorphism within, ultramafic lithologies (Spandler et al., 2011; Lafay et al., 2013; Deschamps et al., 2013; Scambelluri et al., 2014; Barnes et al., 2014; Cannao et al., 2015), so that samples close to contacts may have had a fundamentally different metamorphic evolution compared to the samples from larger ultramafic units.

In this study, opaque phase assemblages in HPLT ultramafic samples from supra-subduction zone and magma-poor rifted margin settings are documented and compared. The compositions of fluids in equlibrium with these assemblages are calculated via thermodynamic calculations that quantitatively constrain the activities of $\mathrm{O}_{2}$ and $\mathrm{S}_{2}$ under HPLT conditions for the first time. The results are used to assess the influences of geodynamic setting, protolith, metasomatism, and prograde metamorphic reactions on the 
evolving redox budget of ultramafic rocks. The results are discussed in the context of current knowledge of these systems and the potential of serpentinised ultramafic rocks to oxidise or reduce the sub-arc mantle and deep Earth. Further, the redox budget of arc products from different geodynamic settings is discussed in the context of the idea that geodynamic setting influences redox changes within subduction and supra-subduction environments.

\section{Geological Setting}

\subsection{New Caledonia}

New Caledonia comprises terranes of Cretaceous to Paleogene age that accreted to, or developed on, the north-eastern margin of a rifted fragment of the Australian plate (Aitchison et al., 1995) (Fig. 17). The Massif du Sud (NC09-01a) lies on the south eastern end of New Caledonia. This unit is a relatively large ultramafic body, tens of $\mathrm{km}$ in lateral extent, but less than $2 \mathrm{~km}$ thick, that was obducted in the Eocene (Ghent et al. 1994 Aitchison et al., 1995). Geochemical data and mineralogy suggest a supra-subduction zone setting for the ophiolite prior to obduction (Dupuy et al., 1981; $\mathrm{Pi}$ rard et al., 2013). The north east tip of New Caledonia hosts ultramafic rocks within the HPLT Pouébo terrane. This terrane consists of eclogite and transitional eclogite mafic, sedimentary, and ultramafic lithologies, and is thought to have undergone peak metamorphic conditions of $1.8 \mathrm{GPa}$ and $590^{\circ} \mathrm{C}$ (Clarke et al., 1997; Carson et al., 2000). Ultramafic exposures in the Pouébo terrane occur mostly as metre-scale serpentinite pods included in metabasic/and or metasedimentary rocks, and a talc-rich reaction zone often separates the ultramafic unit from its host (Spandler et al., 2008). These 
ultramafic pods are thought to have become entrained in the high pressure terrain as a result of tectonic interaction between the mantle hangingwall and the subducted slab (Fitzherbert et al., 2004; Spandler et al., 2008).

\subsection{Zermatt Saas Zone ophiolite}

Prior to Alpine orogenesis, the Alpine domain consisted of two plates, the Adriatic/African plate to the south, and the European plate to the north, separated by an ocean basin, Alpine Tethys. The main part of this ocean basin is known as the Piemonte-Ligurian, or South Penninic basin Beltrando et al. 2014). During Alpine orogenesis from the late Cretaceous onwards, parts of the Tethyan ocean floor were incorporated into the Alpine nappe stack as ophiolitic units. The Zermatt Saas Zone represents the high-pressure metamorphic component of the western Alpine Piemonte Ophiolite. The Piemonte Ophiolite separates structurally lower basement rocks of European affinity (Monte Rosa, Dora Maira, Gran Paradiso) from structurally higher Austroalpine crust represented by the Sesia Zone and Dent Blanche Nappe 105 (e.g. Li et al., 2004; Rebay et al., 2012). Within the Piemonte Ophiolite the Zermatt Saas Zone lies structurally below lower metamorphic grade, greenschist facies, rocks of the Combin Zone (Fig. 1b). The Zermatt Saas and Combin Zones are separated, in places, by slivers of metasedimentary rocks, the Pancherot-Cime Bianchi rocks (Beltrando et al., 2014). Sediments also lie between the Zermatt Saas Zone and the structurally lower Monte Rosa rocks. These sediments include manganese-rich units such as the Gornergrat zone, which is thought to be a sedimentary units deposited on the Monta Rosa crystalline basement (Bearth and Schwandler, 1981) (Fig. 1b).

It has been proposed that the Zermatt Saas Zone was originally lo- 

calities in the New Caledonian Massif du Sud $(n>20)$, the high pressure Pouébo terrain in New Caledonia ( $n=7$, from three sites in the Zermatt Saas Zone ophiolite in the Western Alps: Pfulwe (Switzerland), $n=3$; the 
Gressoney valley (Italy), $n=10$; and the Upper Valtournenche in the Val 


\subsection{Microanalysis}

Polished sections were made, without water in most cases, of samples from all localities. All samples were examined in reflected and transmitted relationships, and a representative sample from each locality was chosen for this study on the basis that the sample exhibited a typical silicate and observed opaque phase mineralogy. Opaque phases in serpentinites are often only a few microns in diameter, and are present in low modes, so an automated mapping technique was used to speed up data collection, effectively eliminate the possibility that small rare phases would be missed, and ensure that results from the samples investigated could be compared in a robust way.

Old carbon coats were removed and the sections were repolished with 1 micron diamond paste before sonication for 10 minutes in ethanol and recoating with carbon. After reflected and transmitted light optical microscopy, the opaque mineral assemblage was determined using the Oxford Instruments Feature Mapping facility on the MIRA TESCAN Field Emission Gun Scanning Electron Microscope (FEG-SEM) at the Microscopy and Microanalysis Facility (MMF) at Curtin University. Feature mapping utilises an automated search for grains with a BSE brightness higher than a user-defined value. The accelerating voltage was either 20 or $25 \mathrm{kV}$. The minimum size of feature recognised was 0.5 microns in the longest dimension. Contrast was adjusted such that Cr-poor magnetite had a brightness of about 170, on a scale of 1 to 255 . Then, the lower threshold for feature recognition was set to a brightness slightly higher than that of Cr-poor magnetite. The total 
analysis time was 3 to 12 hours per sample, depending on the number of features recognised.

The detector was optimised on copper tape prior to each run, and the 
ference on $\mathrm{Fe}$ ), $\mathrm{Cr}_{2} \mathrm{O}_{3}$, Ni and V. Off-peak background corrections were used throughout with an on-peak counting time of 20 seconds per element. Data reduction was performed using the Probe for EPMA software package. WDS was performed on the MIRA TESCAN FEG-SEM at Curtin University. The instrument was operated with an accelerating volatage of $20 \mathrm{KeV}$, a working distance of $15 \mathrm{~mm}$ and a beam intensity of 14 . Analyses were continued until 500,000 counts were obtained. Beam current was set prior to each analytical session by calibration on a cobalt standard set into the mount that holds the thin section, so that the same working distance and beam conditions could be used for both calibration and analysis. Element and oxide concentrations were calculated by the Oxford Instruments software, using factory calibration, which produced good results for the phases of interest in an Astimex standard block. The quality of the EDS analyses was tested by comparison with WDS analyses of the same phases using the JEOL hyperprobe and the repeatability and accuracy was found to be good, with a greater variation found within samples as a consequence of natural heterogeneity rather than between analysis methods.

\subsection{Thermodynamic Modelling}

$a \mathrm{O}_{2}-\sum \mathrm{S}$ or $a \mathrm{O}_{2}-\mathrm{H}_{2} \mathrm{~S}$ activity diagrams for the Fe-Ni-O-S and Fe-NiO-H-S systems at specified temperatures and pressures less than $0.2 \mathrm{GPa}$ have been produced by Frost (1985); Klein et al. (2009) and Foustoukos et al. (2015). The underlying topology of these diagrams is relatively insensitive to temperature over the range of serpentine stability, although absolute values of $a \mathrm{O}_{2}$ and $a \mathrm{H}_{2} \mathrm{~S}$, and activity relative to buffers such as FMQ 
(fayalite-magnetite-quartz) and PPM (pyrite-pyrrhotite-magnetite), change with pressure and temperature.

Pressures in subduction zones at the temperatures of interest are well 
oxygen fluid is 1 at the pressure and temperature of interest. Note that here we are mostly using the term activity, rather than the more commonly used fugacity. The relationship between fugacity and activity is

$$
\log _{10} f_{i}=\frac{1}{2.303 \mathrm{RT}}\left(\mu_{P T}^{\ominus}-\mu_{1 \mathrm{bar}, \mathrm{T}}^{\ominus}\right)+\log _{10} a_{i} .
$$

Here $f_{i}$ is the fugacity of species $i, \mu_{P T}^{\ominus}$ is the chemical potential of the pure species at the $P$ and $T$ of interest, $\mu_{1 \mathrm{bar}, \mathrm{T}}^{\ominus}$ is the chemical of the pure species at the $T$ of interest and 1 bar, and $a_{i}$ is the activity of the species of interest. Activity is preferred here because it does not include the pressure, and is therefore easier than fugacity to compare between different pressuretemperature conditions.

The equations of state for solids and fluids are stated to be valid to $10 \mathrm{GPa}$ (Holland and Powell, 1998). However, caution is required because volumes of the fluid end-members have not been measured, other than for water, at pressures greater than a few tenths of a GPa, so the equations of state for fluid members other than $\mathrm{H}_{2} \mathrm{O}$ are extrapolated beyond the pressures at which they have been tested. However, the form of the corresponding states equation is suggested by Plyasunov (2015) to be valid to water densities around $1000 \mathrm{~kg} \mathrm{~m}^{-3}$, i.e. to pressures of $2 \mathrm{GPa}$ on subduction geotherms, and calculated fugacity coefficients are broadly consistent with those presented by Plyasunov (2015). The EOS are therefore considered semi-quantitative or better at the conditions of interest. Further uncertainty derives from a number of simplifications used in the calculations. These simplifications include the use of the ideal fluid-mixing assumption, the use of pure end-member phases and a consequent lack of consideration of compositional variability, 

in Kelvin, and $K$ is the equilibrium constant. Schreinemaker's analysis was then used to determine the geometry of the phase diagram. The slopes of lines were calculated, where necessary, using the stoichiometry of the reac- 
tions represented by the lines. Constraints on the activities of $\mathrm{O}_{2}$ and $\mathrm{S}_{2}$ during metamorphism were obtained by comparison of the inferred stable opaque phase assemblages with calculated $a \mathrm{O}_{2}-a \mathrm{~S}_{2}$ diagrams. Deviation of $a \mathrm{O}_{2}$ from FMQ $\left(\Delta \mathrm{FMQ}=\log a \mathrm{O}_{2}-\log a \mathrm{O}_{2, \mathrm{FMQ}}\right)$ was also calculated.

An additional constraint is necessary to calculate the position of four phase assemblages in the system $\mathrm{Fe}-\mathrm{Ni}-\mathrm{O}-\mathrm{H}-\mathrm{S}$, because the four phase assemblages that are common in the rocks are trivariant in this system so the activities of fluid species are not uniquely constrained simply by specification of pressure and temperature. Fluid compositions in this system were therefore calculated for a specified total concentration of sulfur species, assuming that $\sum_{i} X\left(\mathrm{~S}_{i}\right)=1-X\left(\mathrm{H}_{2} \mathrm{O}\right)-X\left(\mathrm{H}_{2}\right)$, where $\sum_{i} X\left(\mathrm{~S}_{i}\right)$ is the sum of sulfurbearing species $\mathrm{H}_{2} \mathrm{~S}$ and $\mathrm{S}_{2}$. For these preliminary calculations, activities were assumed to be equal to mole fractions, that is, the fluids were assumed to mix ideally. The effects of this assumption are addressed below. Fortunately sulfur has very limited solubility so plausible values of $X\left(\mathrm{H}_{2} \mathrm{O}\right)+$ $X\left(\mathrm{H}_{2}\right)$ range from 0.95 to 1 . Using this additional compositional constraint, the fluid composition can be calculated by solution of a system of non-linear equations that describe a set of independent reactions, as for the Fe-Ni-O-S system.

\section{Results}

\subsection{Bulk composition}

Bulk compositions of the New Caledonia peridotites are typical of hydrated harzburgite from New Caledonia (Evans, 2012). The total iron content of Zermatt Saas Zone samples from the Upper Valtournenche and Pfulwe 
is around $11.5 \mathrm{wt} \%$, which is at the iron-rich end of values recorded in the literature for ultramafic rocks from the Zermatt Saas Zone (Li et al., 2004), Cima di Gagnone (Scambelluri et al., 2014), the Platta and Malenco units (Muntener et al., 2010), Lanzo and Monviso (Debret et al., 2014a), and other Western Alps locations (Barnes et al. 2014). The iron content in the majority of samples analysed for these previous studies falls in the range between 7 and $10 \mathrm{wt} \%$, with a few samples ranging up to $12 \%$. The third sample, from Gressoney, falls in the more typical compositional range, with total iron, as $\mathrm{Fe}_{2} \mathrm{O}_{3}$ of 8.4 wt\%. Other compositional parameters for the Zermatt Saas Zone samples fall in the typical compositional range for the Zermatt Saas Zone defined by the analyses of previous workers, with the exception of the Al- and Ti-rich composition of PF001, from Pfulwe, which may reflect some form of chemical or physical mixing with some components of the neighbouring Allalin gabbro, and/or melt-rock interaction.

\subsection{Non-opaque mineralogy}

In all samples, the non-opaque mineral assemblage comprises one or more

350 drous alteration products, serpentine (lizardite or antigorite) \pm chlorite \pm brucite \pm talc (Table 3 ). In detail, the assemblage varies as a function of bulk composition, metamorphic grade, and the extent of hydration. Comprehensive descriptions of the silicate mineral assemblage for these localities

Caledonian samples, by Li et al. (2004), Groppo et al. (2009), and Reddy et al. (1999) for the Zermatt Saas Zone samples, but relevant details are summarised briefly here. 
Serpentine is the dominant silicate mineral in all sections ( $>80 \%$ by voltween 550 and $600{ }^{\circ} \mathrm{C}$ for the subducted samples. The reasoning is that olivine grows as a consequence of brucite destruction from about $450{ }^{\circ} \mathrm{C}$, but 
brucite would have been absent in the higher Si:Fe+Mg rocks LC-015 and (GSZ-11a, Fig. 2d). Magnetite compositions vary significantly. For example, Cr-rich magnetite cores in NC07-60 that contain awaruite inclusions are overgrown by Cr-poor magnetite to form a skeletal maze-like composite of 
crystals (Figure 3a), whereas Ti-rich magnetite cores surrounded by ilmenite occur in PF-001. See below for a more detailed discussion of magnetite compositional variations.

The accessory phase assemblage, other than magnetite, is variable (Table 3). Magnetite is accompanied by awaruite $\left(\mathrm{FeNi}_{3}\right)$, heazlewoodite $\left(\mathrm{Ni}_{3} \mathrm{~S}_{2}\right)$, native $\mathrm{Cu}$, platinum group minerals and pentlandite (nominally $\mathrm{Fe}_{4.5} \mathrm{Ni}_{4.5} \mathrm{~S}_{9}$ ) in NC09-01a (Fig. 4a), with texturally late millerite (NiS). These phases are interpreted to have developed during serpentinisation.

In contrast, NC07-60 contains almost no S-bearing phases so that the opaque phase assemblage is simply magnetite and awaruite plus a single, possibly late, small (<10 microns), pentlandite grain (Figs 3a,b, 4d). Awaruite in NC07-60 has indented boundaries adjacent to serpentine (Fig. 4d), which is interpreted to suggest that the mode of this mineral was decreasing when metamorphism was arrested by exhumation.

GSZ-11a is the only one of the Zermatt Saas Zone samples to contain Ni-bearing phases, with early awaruite, heazlewoodite and pentlandite overgrown by later magnetite and millerite (NiS) (Figs 44,d). Pentlandite and magnetite are in contact with the antigorite matrix and are therefore assumed to be part of the prograde metamorphic assemblage.

In the other two Zermatt Saas Zone samples, PF-001 and LC-015, magnetite is accompanied by small amounts of pyrite, plus, in the case of LC-015, barite. The textural setting of the pyrite and barite is difficult to determine because the grains are small and are often located at grain junctions. However, there is no evidence that these phases are late so they are taken to be present during peak metamorphism. PF-001 also contains ilmenite, 
sphalerite, and chalcopyrite. Monazite was observed in LC-015 and PF-001. (Table S3e).

Magnetite exhibits a wide range of composition (Table S3f). Magnetite in NC09-01a is almost pure $\mathrm{Fe}_{3} \mathrm{O}_{4}$, with minor $\mathrm{Mg}$, while magnetite in NC07-60 
shows a variable proportion of $\mathrm{Ni}$, up to 0.1 moles per four oxygen formula

unit, and Cr-rich cores (Fig. 3a). Magnetite compositions in PF-001 are also highly variable, with Ti-rich magnetite that occurs surrounded by ilmenite, and almost pure pure $\mathrm{Fe}_{3} \mathrm{O}_{4}$ as late cross-cutting grains in the matrix. Similarly, late magnetite in GSZ-11a is almost pure $\mathrm{Fe}_{3} \mathrm{O}_{4}$ but magnetite inferred to be compositionally earlier on textural grounds is variably Cr-rich, with up to 0.2 moles of Cr per four oxygen formula unit. LC-015 displays a similar temporal evolution in magnetite composition, with Cr-rich cores to magnetite, and close to pure $\mathrm{Fe}_{3} \mathrm{O}_{4}$ magnetite on the rims of Cr-rich grains and in the matrix.

Awaruite grains large enough to analyse were found only in NC07-60, and $X(\mathrm{Ni})$ in these grains is $>0.8$, at $0.862 \pm 0.003(\mathrm{n}=3)$, rather than the 0.75 expected for stoichiometric awaruite (Table S3g). This result was repeated using both EDS and WDS, and is also consistent with the large number of EDS analyses obtained during the feature mapping. Sulfides large enough for analysis were found only in GSZ-11a. Millerite compositions were close to stoichiometric NiS, with $X(\mathrm{Fe})<0.02$ in all cases (Table S3h, $\mathrm{n}$ $=20$ ). Heazlewoodite grains were also close to stoichiometric $\mathrm{Ni}_{3} \mathrm{~S}_{2}$, with $X(\mathrm{Fe})$ between 0.01 and 0.08 , but generally at the lower end of this range (Table S3h, $\mathrm{n}=40$ ). Ilmenite in PF-001 is close to stoichiometric, whereas ilmenite in LC-015 is Mn- and Mg-rich, with $X(\mathrm{Fe})$ on the divalent site as low as 0.4 .

\subsection{Thermodynamic Modelling}

The assemblage inferred to be present at peak pressure and temperatures for each section was plotted onto an $a \mathrm{O}_{2}$ vs. $a \mathrm{H}_{2} \mathrm{~S}$ diagram after Klein et al. 
(2009) (Fig. 5). There is a clear distinction between the awaruite-bearing New Caledonia samples and the awaruite-absent Alpine samples. Calculations at higher pressures (Fig 6), which are considered semi-quantitative or better also show a significant difference between the positions of the two samples sets in $a \mathrm{O}_{2}-a \mathrm{~S}_{2}$ space. Calculations in the system Fe-Ni-O-H-S indicate that the New Caledonia samples equilibrated with $\mathrm{H}_{2}$-bearing fluids $X\left(\mathrm{H}_{2}\right)$ $490>0.01$, in clear contrast to the water-rich fluids calculated for assemblages in the Alpine samples, which have $X\left(\mathrm{H}_{2}\right)<0.00001$.

Increasing pressure shifts conditions for the buffering assemblages awaruiteheazlewoodite-magnetite-pentandite (AMPZ), pyrite-pyrrhotite-magnetite (PPM) and hematite-pyrite-magnetite (HMP) to lower $a \mathrm{~S}_{2}$ and higher $a \mathrm{O}_{2}$ (Fig 6) but in most cases the relative position of the buffers is not much affected by the changes in pressure and temperature. Thus the difference in inferred peak pressure between New Caledonia sample NC07-60 (1.6 GPa) and the Upper Valtournenche sample LC-015 (2.4 - 2.8 GPa) does not affect conclusions drawn from Fig. 6.

An exception to the consistent relative geometry of the phase diagrams as a function of pressure is the position of millerite-vaesite reaction relative to the trivariant hematite-pyrite reaction. The millerite - vaesite reaction cuts the trivariant hematite-pyrite reaction at lower pressures, and the magnetitepyrite reaction at $2 \mathrm{GPa}$. The univariant assemblage magnetite - pyrite vaesite - millerite - hematite is stable only at approximately $1.25 \mathrm{GPa}$ on the inferred geotherm. Thus co-existing magnetite and vaesite can be inferred to have formed at pressures greater than $1.25 \mathrm{GPa}$, while vaesite is expected to co-exist with hematite pressures less than 1.25 GPa. Unfortunatley, vaesite is 
not present in any of the studied rocks, so this pressure sensitivity, while potentially useful as a geobarometric indicator, does not affect the conclusions presented here.

\section{Discussion}

\subsection{Subduction fluid compositions}

The principal result of this study is that the New Caledonia samples contain awaruite and co-existed with hydrogen-bearing fluids at $\triangle \mathrm{FMQ}$ around -3 at peak pressure and temperature, while the Alpine samples contain pyrite or millerite and equilibrated with water-dominated fluids at $\triangle \mathrm{FMQ}-1$ to +2 . Traces of an earlier awaruite-bearing assemblage are present in one of the Alpine samples, GSZ-11a, so at least one of the Alpine samples evolved from low $a \mathrm{O}_{2}$ fluids to higher $a \mathrm{O}_{2}$ fluids during its history. It is interesting to explore the cause and conseqences of this striking difference in fluid oxidation state.

\subsection{Causes of $a \mathrm{O}_{2}$ variability in serpentinites}

Serpentinisation proceeds in two distinct stages (Delacour et al., 2008; Alt and Shanks, 1998; Klein et al., 2009, Frost et al., 2013). In the first stage, at low time-integrated water:rock ratios, awaruite is stable along with brucite, Ni-sulfides, (heazlewoodite or pentlandite), \pm magnetite \pm native copper, and fluid compositions are silica-poor, highly reducing, and may induce desulfidation (Frost and Beard, 2007, Klein et al., 2009; Frost et al., 2013; Auge et al., 1999; Evans et al., 2009; Gonzalez-Jimenez et al., 2011; Schwarzenbach et al. 2014). This initial stage, arguably, lasts as long as 
olivine and brucite form part of the same equilibration domain as the infiltrating fluid (Evans et al., 2013; Frost et al., 2013), though see Evans et al. (2012a) for an alternative view.

Once time-integrated water:rock ratios increases beyond some critical value, olivine loses chemical connection to the infiltrating fluid and the rock enters the second stage of serpentinisation. Awaruite and brucite are lost, and fluid compositions evolve to higher $a \mathrm{O}_{2}$ and higher Si-activity compositions. The rock develops an assemblage of serpentine, magnetite \pm sulfur-rich sulfides \pm isolated relict peridotite phases. Such serpentinites are described in oceanic settings from IODP hole 1309D (Delacour et al., 2008), at ODP Leg 209, at the 15 degrees 20 minutes N Fracture zone on the Mid Atlantic Ridge (Klein et al., 2009), and at the Iberian margin ocean-continent transition (Alt and Shanks, 1998; Schwarzenbach et al., 2012, 2013). Similar assemblages are also recorded in Ligurian ophiolites from the Northern Apennines where most features are thought to record seafloor metamorphism Alt et al. $2012 \mathrm{~b})$.

During subduction and deserpentinisation the mineral assemblage continues to buffer fluid composition until the buffer is exhausted or until prograde mineral changes alter the buffer. Thus, subducted stage one serpentinites with awaruite would buffer fluids to low $a \mathrm{O}_{2}$, and stage two serpentinites would buffer fluid compositions to high $a \mathrm{O}_{2}$, at least until prograde olivine growth begins. Both types of assemblages have been reported in studies of HPLT rocks in addition to this one. Awaruite-bearing stage one assemblages 555 have been recorded in HPLT rocks and contact metamorphosed HPLT rocks (e.g. Nozaka, 2003; Arif and Moon, 1996; Peretti et al., 1992), and it has 
been proposed awaruite may grow with prograde olivine during prograde HPLT metamorphism (Peretti et al., 1992; Groppo and Compagnoni, 2007). Stage 2 assemblages are recorded by samples from the Beigua unit of the Voltri massif ( $T$ to $550{ }^{\circ} \mathrm{C}, P$ to $2.5 \mathrm{GPa}$ ), which contain pyrite, pyrrhotite and magnetite (Mottana and Bocchio, 1975, Messiga and Scambelluri, 1991; Scambelluri et al., 1997; Vignaroli et al., 2005; Alt et al., 2012b).

Mineral assemblages and fluid compositions in the New Caledonian and Zermatt Saas Zone are consistent with stage one and stage two assemblages respectively. It is therefore useful to explore the idea that fluid composition during HPLT metamorphism is related to the relative progress of the two phases of serpentinisation that occur prior to subduction.

\subsection{Serpentinising environment and geodynamic setting}

The dominant control on the progression from stage one to stage two of serpentinisation is time-integrated water:rock ratio, although the composition of infiltrating fluid and the presence or absence of active deformation are also influential.

It is reasonable that water:rock ratios during serpentinisation of the New Caledonia rocks were lower than those during serpentinisation of the Zermatt Saas Zone rocks. The New Caledonia rocks were serpentinised in a SSZ setting (Fitzherbert et al., 2004; Cluzel et al., 2012), and here the awaruitebearing assemblage of NC09-01a attests to the relatively low fluid:rock ratios in this setting. During serpentinisation of the protolith to the Zermatt Saas Zone ophiolite, on the other hand, water:rock ratios would most likely have been relatively high. The Zermatt Saas Zone is one of a string of ophiolites thought to have been part of either the magma-poor rifted margin to the 
Tethyan ocean or its magma-poor slow spreading centre Bernoulli et al., 2003; Lagabrielle, 2009; Manatschal and Muntener, 2009; Muntener et al., 2010: Lagabrielle et al., 2015). It is not possible at this stage to specify

the geodynamic setting of the Zermatt Saas Zone unambiguously. However, the slow spreading ridge and magma-poor OCT settings are similar environments with respect to seawater infiltration and serpentinisation, because mantle lithosphere is exposed at, or close to, the seafloor. Under either slowspreading or OCT conditions, time integrated fluid:rock ratios can be high, and serpentinisation is likely to progress to stage two.

There is abundant evidence for extensive pre-subduction serpentinisation in the Zermatt Saas Zone ophiolite. This evidence includes pseudomorphic textures of serpentine after olivine, which are typical of ocean floor serpentinisation (Li et al., 2004; Rebay et al., 2012; Fontana et al., 2008). There is also evidence of rodingitisation at contacts between the Zermatt Saas Zone serpentinites and basaltic dykes (Li et al., 2008). Rodingitisation records relatively low temperature $\left(<300{ }^{\circ} \mathrm{C}\right)$ fluid - rock interaction and is known to occur in ocean floor settings (Beard et al., 2009). Ophicarbonate breccias have been reported at Chatillon in the Zermatt Saas Zone ophiolite by Driesner (1993), and contacts between ultramafic lithologies and metacherts have been documented and interpreted as a record of ultramafic rocks at the ocean crust-sediment interface (Bearth and Schwandler, 1981).

A difference in the percentage of mantle lithosphere that is serpentinised in magma-rich and magma-poor settings is supported by the literature. In the Hess Deep, rifted fast spreading oceanic crust bears awaruite Alt and Shanks, 1998), indicative of stage one of serpentinisation, while the mantle 
lithosphere underlying most of the Atlantic Ocean is estimated to be less than $6 \%$ serpentinised by Carlson (2001), although estimates vary. In contrast, at the West Iberian margin, a passive margin associated with an oceancontinent transition, estimates of the serpentinised fraction range up to $28 \%$ for peridotite overlain by thin crust (Skelton et al., 2005), and from 25-100\% for exhumed mantle that is thought to have undergone seawater percolation aided by hydrothermal circulation (Dean et al. 2000). This variation in the extent of serpentinisation is likely to be coupled with a variation in the stage of serpentinisation, so that rocks from fast-spreading settings are more likely to retain the stage one assemblage that leads to release of low $a \mathrm{O}_{2}$ fluids during deserpentinisation, consistent with the results of Alt and Shanks (1998).

An additional complexity is that the time-integrated fluid rock ratio for any serpentinite may increase at the initiation of subduction because fluid infiltration occurs as the slab bends to enter the subduction zone Ranero and Sallares, 2004; Lefeldt et al., 2012; Naif et al., 2015). The depth and geometry of fluid infiltration is controlled by the depth of normal faulting at the bend and is still poorly understood (Lefeldt et al., 2012). However, it is likely that lithologies close to the top of the slab are more likely to be infiltrated than those lower down, and to be infiltrated more extensively. Thus, ultramafic rocks are at or close to the top of the subducting slab, as would occur for ocean crust from magma-poor or OCT settings, would undergo a greater degree of fluid infiltration and serpentinisation than ultramafic rocks concealed beneath several $\mathrm{km}$ of intrusive and extrusive mafic rocks.

It is therefore plausible that geodynamic setting is a primary control on 
the time-integrated fluid rock ratio that drives serpentinisation, and that serpentinites from magma-poor and OCT settings, where ultramafic rocks are readily accessed by seawater, are the most likely to reach stage two of serpentinisation. Other settings that undergo extensive fluid-rock interaction include transform faults, oceanic core complexes, and exhumed mantle at rifted continental margins. Geodynamic setting, therefore, may provide a first order control on the redox characteristics of fluids released by serpentinites in subduction zones.

How general is the conceptual model and how representative are the results?

The proposed fluid-rock regimes may not apply to all rocks in a particular geodynamic setting because fluid flow in the Earth's crust is heterogeneous. Such heterogeneity is evident in well studied present day oceanic settings. For example, most serpentinised peridotites at the MARK area on the midAtlantic ridge contain millerite, typical of stage two serpentinisation, but some samples contain locally developed awaruite (Alt et al., 2003). Similarly, metamorphic awaruite in the Alps documented by Peretti et al. (1992) at Val Malenco, by Diella et al. (1994) at the Mt. Avic area in the Zermatt Saas Zone ophiolite, by Zucchetti et al. (1988) at the Balangero mine in the western Alps, and by Carbonin et al. (2015) for the Cogne unit, in the Western Alps, attests to the fact that not all serpentinites derived from Tethyan oceanic lithosphere evolved in equilibrium with water-rich fluids. These examples demonstrate the heterogeneity of fluid flow within mantle lithosphere on the ocean floor. Nevertheless, we propose that ultramafic rocks derived from magma-poor OCT and slow and ultra-slow spreading ridge settings are likely to be, on average, more serpentinised than ultramafic 
rocks from SSZ settings and therefore to produce fluids with $a \mathrm{O}_{2}$ greater than FMQ during subduction.

It must also be considered that only a small number of samples could representative in terms of their silicate mineral assemblages, which are are consistent with those reported by previous workers (Barnicoat and Fry, 1986 ; Reddy et al., 1999; Li et al., 2004; Fitzherbert et al., 2004, Groppo et al., 2009; Rebay et al., 2012; Frost et al., 2013; Gasco et al., 2013), except that titanoclinohumite was not present in the selected samples from the Zermatt Saas. Titano-clinohumite samples were present in the sample suites from which the selected samples were chosen, but were not selected for this study because a comprehensive discussion of the controversial genesis of titano-clinohumite ¿Was considered outside the scope of this work (Rahn and Bucher, 1998; Li et al., 2004; Rebay et al., 2012), and because these samples form the topic of work in progress. These samples are also representative of the larger sample suites in terms of their opaque phase assemblages, so far as can be determined from optical microscopy alone. The results are also consistent with those of other workers who infer high $a \mathrm{O}_{2}$ fluids for Alpine HPLT rocks (see section 5.5 .1 .

\subsection{Alternative explanations: protolith bulk composition}

It is necessary to consider if the difference in fluid compositions could have been caused by factors other than the extent of pre-subduction serpentinisation, such as protolith bulk composition. The opaque phase assemblage in the three Zermatt Saas Zone samples implies similar metamorphic $a \mathrm{H}_{2}-a \mathrm{H}_{2} \mathrm{~S}$ - $a \mathrm{~S}_{2}$ but their protoliths are significantly different. GSZ-11a has relatively 
low Si: $\mathrm{Fe}+\mathrm{Mg})$ compared to PF-001 and LC-015, whereas the presence of chlorite and ilmenite in PF-001 indicate its Al- and Ti-rich bulk composition (Table 4). PF-001 and LC-015 are both iron-rich relative to the Gressoney sample, GSZ-11a, and also to other serpentinites from both the Zermatt Saas Zone and elsewhere the Western Alps (Li et al., 2004; Muntener et al., 2010; Barnes et al., 2014; Debret et al., 2014a; Scambelluri et al., 2014). In spite of these differences, similar petrological features are observed in the three of the Zermatt Saas Zone samples studied here, and in the majority of other samples from the Western Alps. Additionally, the bulk composition of the New Caledonia samples is very similar to that of GSZ-11a, but the mineral assemblage and inferred fluid composition are significantly different. Combination of these observations suggest that protolith bulk composition is not the cause of the observed systematic difference in fluid composition between the Zermattt-Saas and New Caledonian locations.

\subsection{Alternative explanations: input from adjacent lithologies}

The nature of units adjacent to the studied metaperidotites must also be considered as a potential cause of the observed systematic differences in fluid composition between the two localities. There is significant variation in the units currently adjacent to the Zermatt Saas Zone samples but this variation is not related to redox aspects of the inferred fluid composition. LC-015 was sampled within 50 metres of a Mn-rich sedimentary sequence, while PF-001 was sampled within 20 metres of the Allalin gabbro. It is plausible that proximity to the Allalin gabbro affected the bulk composition of PF-001, as

recorded by the high proportion of Ti-bearing phases in this sample (Table 3). However, the redox aspects of the fluid compositions inferred for all three 
of the Zermatt Saas Zone samples are indistinguishable and significantly different to those for the New Caledonia samples, so it is proposed that while adjacent lithologies may affect some aspects of fluid chemistry, their proximity had, at best, a second order effect on the redox state of fluids.

\subsubsection{Other evidence for oxidised fluids in Alpine HPLT rocks}

There is a growing body of evidence for the presence of high $a \mathrm{O}_{2}$ fluids in HPLT rocks in the Alps. The presence of diamond in metasediments from Lago di Cignana has been interpreted to record water-rich fluids on the EMOD (enstatite-magnetite-olivine-diamond) redox buffer (Frezzotti et al., 2014). Debret et al. (2015) record a decrease in whole rock $\mathrm{Fe}^{3+} / \mathrm{Fe}_{\text {tot }}$ at the antigorite dehydration isograd at Cerro de Almirez, which occurred at the pressures and temperatures found in the cooler parts of the mantle wedge. This result is interpreted as the consequence of loss of redox budget in fluids, 720 consistent with the suggestion of Alt et al. (2012a) that sulfate was lost from these rocks during serpentinite dehydration. In the Western Alps, Debret et al. (2016) interpret hematite laths in magnetite as a record of high oxygen activity, and a correlation between whole rock $\mathrm{Fe}^{3+} / \mathrm{Fe}_{\text {tot }}$ and iron isotopes in rocks as evidence of the loss of oxidised sulfur in fluids. Further, Tumiati et al. (2015), document sulfates and hematite in manganese ores hosted by metasediments thought to have reached $2 \mathrm{GPa}$ at Praborna, in the Italian Western Alps.

These results are consistent with those from this study. The presence of late or post-foliation magnetite in all four high pressure samples is consistent with infiltration of fluids capable of oxidising iron after formation of the dominant foliation (e.g. Fig. 2, Table S3f). Late magnetite displays talc 
rims in some cases, and the restricted pressure range of talc stability suggests that this late magnetite grew at pressures greater than 1 GPa (Evans and Powell, 2015), i.e. during the early stages of exhumation. At this time,

\subsection{Consequences: arc outputs}

We have hypothesised that subduction of mantle lithosphere serpentinised in magma-poor oceanic or rifted continental margin settings may lead to release of fluids more oxidised than those associated with subduction of mantle from other geodynamic settings. If this is the case then products from arcs associated with subduction zones that consume mantle lithosphere from magma-poor settings might be expected to record this additional redox budget.

The extent of changes to the redox budget of the sub-arc mantle depends on the magnitude of fluid release; serpentinised oceanic lithosphere is thought to make up only a few weight percent of that subducted globally Carlson, 2001; Cannat et al., 2010), and material produced at slow and ultra-slow

755 spreading ridges is only subducted, at the present day, at the Antilles and Scotia arcs (Alt et al., 2013). Thus, the effects of subduction of extensively 
serpentinised mantle lithosphere at the present day may be localised and minor. However, as noted by Alt et al. (2013), the role of subducted serpentinites may have been greater in the Cretaceous, when Tethyan ocean floor produced at slow and ultra-slow spreading ridges in the Jurassic was subducted.

Evans (2012) calculated the redox budget of primitive arc magmas for a selection of arcs including those that consume crust from the fast-spreading ridges in the Pacific Ocean and those from the magma-poor Mid-Atlantic Ridge. These data display a statistically significant correlation between redox budget, subduction zone age and convergence rate. The Antilles arcs, which sample subducted MAR-produced lithosphere, lie on the same trend as the Aleutians, Kurile, Izu-Bonin, and other arcs that sample Pacific-ridgeproduced lithosphere, so at first sight the subducted lithosphere type is not 770 a first order control on the average redox budget of the whole arc. However, if the areas of seaflloor formed at spreading rates $<40 \mathrm{~mm} \mathrm{year}^{-1}$ by Cannat et al. (2010) are considered then it can be seen that crust produced at slow spreading ridges is only entering subduction zones at the very tip of the Antilles subduction zone, and along the Scotia subduction zone. Few data 775 from the Scotia subduction zone include analysis of both ferric and ferrous iron, so at present it is not possible to properly assess the consequences of subduction of mantle lithosphere serpentinised in magma-poor environments. Further detailed studies of local arc segments are required if the hypotheses presented here are to be tested. 

2013).

The oxidation state of subduction fluids affects sulfur mobility, because the limited data available suggests that oxidised sulfur fluid species are more soluble than reduced species. Anhydrite solubilities of up to 6 molal in salt- 
2005). $\mathrm{H}_{2} \mathrm{~S}$, on the other hand, is only sparingly soluble, with reported solubilities in fractions of moles per litre (Barrett et al., 1988; Suleimenov and Krupp, 1994), although the experiments on which these values are based were undertaken at relatively low pressures and temperatures $\left(<320{ }^{\circ} \mathrm{C},<0.1\right.$ GPa). The $\mathrm{SO}_{2} /$ sulfide ( $\mathrm{SSO} 2$ ) transition in aqueous fluids is calculated to occur at oxygen activities just above the pyrite-pyrrhotite-magnetite (PPM) buffer at $0.5 \mathrm{GPa}$ and $800{ }^{\circ} \mathrm{C}$, (Newton and Manning, 2005). Thus sulfur in fluids equilibrated with samples from the Zermatt Saas Zone samples, according to the best evidence available, would have been dominantly $\mathrm{S}(+4)$ in $\mathrm{SO}_{2}$ or $\mathrm{S}(+6)$ in $\mathrm{SO}_{4}^{2-}$. Sulfur in fluids equilibrated with the New Caledonia samples, on the other hand, would have been $\mathrm{S}(2-)$ in hydrogen sulfide, and sulfur mobility would have been limited.

Thus, sulfur is likely to be more effectively mobilised in subduction zones that process extensively serpentinised, and therefore oxidised, mantle lithosphere from magma-poor geodynamic settings. There are two significant consequences if sulfur cycling is more effective when mantle lithosphere from magma-poor settings is subducted. First, transport and deposition of metals that depend on sulfur as a ligand will be more effective in mantle that overlies subducted slab from magma-poor settings. Second, transport of redox budget from the subducting slab to the sub-arc mantle is likely to be more substantial when the subducted crust is magma-poor.

It is difficult to assess the extent of sulfur mobility with the sample set for this study. The number of samples is small, and the $\mathrm{S}$ content varies by a factor of four (Table 4), similar to the range displayed by pre-subduction 
sulfur contents (Alt et al., 2013). Reports of trends in sulfur concentrations „with increasing extent of HPLT metamorphism are inconsistent. Hattori and Guillot (2007) measured sulfur concentrations in five samples from the Monviso ophiolite, which lies south of the Zermatt Saas Zone and underwent HPLT metamorphism (Messiga et al., 1999, Schwartz et al., 2000; Castelli et al., 2002; Spandler et al., 2011). S concentrations varied from below the detection limit of 5 ppm to $2410 \mathrm{ppm}$. In another study, Alt et al. (2012b) compared sulfur concentrations in Ligurian serpentinites from the Apennines, which are largely unaffected by HPLT metamorphism, with serpentinites from the Voltri massif. Ultramafic rocks in the Voltri massif, like the Zermatt Saas Zone, are thought to have been part of slow-spreading or OCT Tethyan mantle lithosphere, and to have been subducted and metamorphosed at peak pressures and temperatures of $550{ }^{\circ} \mathrm{C}$ and $2-2.5 \mathrm{GPa}$ Messiga and Scambelluri, 1991; Vignaroli et al., 2005). There was no significant difference in the sulfur contents between the localities affected and unaffected by the HPLT metamorphism. On the other hand, Debret et al. (2014b) measured sulfur concentrations in serpentine hosted by samples from Alpine ophiolites from different parts of the Alps and metamorphosed to different metamorphic grades. Sulfur in the serpentine showed a decrease in concentration with metamorphic grade. However, bulk composition data for sulfur was not provided so it is not clear if sulfur was transferred to sulfur-bearing minerals and retained, or to a fluid phase, and lost.

Thus, while the effects of pre-subduction geodynamic setting on sulfur mobilisation are potentially significant, existing data emphasise the spatially heterogeneous nature of the sulfur distribution in serpentinites and the need 
for more measurements of whole-rock sulfur concentrations integrated with petrographic and outcrop scale evidence of oceanic and metamorphic fluid flow to constrain the extent of sulfur release.

\subsection{Use of exhumed mantle as an analogue for typical subducted mantle}

Mantle lithosphere exhumed in high pressure terrains presents our best opportunity to examine the effects of subduction on this lithology. However, if the extent of pre-subduction is as influential as is suggested here, then it may be that mantle serpentinised in magma-poor settings may not be representative of much of the subducted lithospheric mantle.

Yet such mantle is the most widely studied; the Alpine ophiolites are disproportionately well represented in the small but growing number of studies of the effects of subduction on the redistribution of redox-sensitive elements (Peretti et al., 1992; Groppo and Compagnoni, 2007; Alt et al., 2012b; Schwarzenbach et al., 2012; Debret et al., 2014a, b, 2015) because the Alps are well exposed, well studied, and relatively accessible. Further, it has been suggested by Beltrando et al. (2010) that magma-poor margins lie in positions favourable for exhumation from HP or UHP metamorphism, because of their location between negatively buoyant oceanic lithosphere and more buoyant continental lithosphere. In contrast, the global subduction budget is dominated by subduction of lithosphere formed at fast and intermediate spreading rates.

Under these circumstances, the use of exhumed mantle lithosphere from magma-poor settings as an analogue for all serpentinised mantle must be undertaken with caution, because conclusions drawn from exhumed mantle lithosphere serpentinised in magma-poor oceanic or rifted continental margin 

the capability of mantle lithosphere to oxidise the sub-arc mantle and deep Earth.

\section{Conclusions}

Opaque phase assemblages in serpentinites from New Caledonia and the Zermatt Saas Zone ophiolite equilibrated at significantly different $a \mathrm{O}_{2}$ during HPLT metamorphism. The assemblages are consistent with the assemblages that would develop in serpentinites that proceeded to stage one and stage two of serpentinisation, prior to subduction, respectively.

The geodynamic setting of serpentinisation is a control on time-integrated water rock ratios seen by serpentinites, and therefore on the stage of serpentinisation reached. Serpentinisation in environments subject to low water:rock ratios, such as SSZ environments and mantle lithosphere underlying thick mafic crust, is likely to proceed only to stage one, while serpentinisation in environments with ready access to fluids, such as mantle lithosphere in slow and ultra-slow spreading environments, and in OCT settings, is likely to proceed to stage 2, although fluid flow is heterogeneous and stage one assemblages can be preserved locally in these overall high water:rock ratio settings.

The oxidation state of fluids produced by serpentinites during subduction therefore depends on the geodynamic setting of pre-subduction serpentinisation. This suggestion, though based on a small data set, is consistent with literature reports, and alternative explanations, such as bulk composition and adjacent lithologies do not explain the observed results. Thus, serpen- 
tinites produced in magma-poor or OCT setting may release more oxidised Laeter Centre. SMR acknowledges support from the ARC Core to Crust 
Fluid Systems COE. The late Marco Beltrando is thanked for stimulating discussions on the relationship of OCTs with high pressure ultramafic rocks of the Alps. Jeffrey Alt and Baptiste Debret, and two anonymous reviewers are thanked for constructive reviews. The MMF (Microscopy and Microanalysis Facility) at Curtin, are thanked for technical and in-kind support. The authors also acknowledge the facilities, and the scientific and technical assistance of the Australian Microscopy and Microanalysis Research Facility at the Centre for Microscopy, Characterisation and Analysis, The University of Western Australia, a facility funded by the University, State and Commonwealth Governments. 


\section{REFERENCES}

Aitchison, J. C., Clarke, G. L., Meffre, S., Cluzel, D., 1995. Eocene arccontinent collision in New Caledonia and implications for regional southwest Pacific tectonic evolution. Geology 23 (2), 161-164.

Alt, J. C., Davidson, G. J., Teagle, D. A. H., Karson, J. A., 2003. Isotopic composition of gypsum in the Macquarie Island ophiolite: Implications for the sulfur cycle and the subsurface biosphere in oceanic crust. Geology $31(6), 549-552$.

Alt, J. C., Garrido, C. J., Shanks, W. C., Turchyn, A., Padron-Navarta, J. A., Sanchez-Vizcaino, V. L., Pugnaire, M. T. G., Marchesi, C., 2012a. Recycling of water, carbon, and sulfur during subduction of serpentinites: A stable isotope study of Cerro del Almirez, Spain. Earth and Planetary Science Letters 327, 50-60.

Alt, J. C., Schwarzenbach, E. M., Frueh-Green, G. L., Shanks, W. C., Bernasconi, S. M., Garrido, C. J., Crispini, L., Gaggero, L., PadronNavarta, J. A., Marchesi, C., 2013. The role of serpentinites in cycling of carbon and sulfur: Seafloor serpentinization and subduction metamorphism. Lithos 178, 40-54.

Alt, J. C., Shanks, W. C., 1998. Sulfur in serpentinized oceanic peridotites: Serpentinization processes and microbial sulfate reduction. Journal of Geophysical Research-Solid Earth 103 (B5), 9917-9929.

Alt, J. C., Shanks, W. C., Crispini, L., Gaggero, L., Schwarzenbach, E. M., Fruh-Green, G. L., Bernasconi, S. M., 2012b. Uptake of carbon and sulfur 
during seafloor serpentinization and the effects of subduction metamorphism in Ligurian peridotites. Chemical Geology 322, 268-277.

Andreani, M., Munoz, M., Marcaillou, C., Delacour, A., 2013. mu XANES study of iron redox state in serpentine during oceanic serpentinization. Lithos 178, 70-83.

Arif, M., Moon, C. J., 1996. Textural and chemical characteristics of olivine and pyroxenes in the ultramafic rocks from the Indus suture zone in Swat, NW Pakistan: Implications for petrogenesis and alteration. Schweizerische Mineralogische Und Petrographische Mitteilungen 76 (1), 47-56.

Auge, T., Cabri, L. J., Legendre, O., McMahon, G., Cocherie, A., 1999. PGE distribution in base-metal alloys and sulfides of the New Caledonia ophiolite. Canadian Mineralogist 37, 1147-1161.

Barnes, J. D., Beltrando, M., Lee, C. T. A., Cisneros, M., Loewy, S., Chin, E., 2014. Geochemistry of Alpine serpentinites from rifting to subduction: A view across paleogeographic domains and metamorphic grade. Chemical Geology 389, 29-47.

Barnicoat, A. C., Fry, N., 1986. High-pressure metamorphism of the ZermattSaas ophiolite zone, Switzerland. Journal of the Geological Society 143, $607-618$.

Barrett, T. J., Anderson, G. M., Lugowski, J., 1988. The solubility of hydrogen-sulfide in $0.5 \mathrm{M} \mathrm{NaCl}$ solutions at 25 -95 degrees $\mathrm{C}$ and one atmosphere. Geochimica Et Cosmochimica Acta 52 (4), 807-811. 
Beard, J. S., Frost, B. R., Fryer, P., McCaig, A., Searle, R., Ildefonse, B., Zinin, P., Sharma, S. K., 2009. Onset and progression of serpentinization and magnetite formation in olivine-rich troctolite from IODP hole U1309D. Journal of Petrology 50 (3), 387-403.

Bearth, P., Schwandler, H., 1981. The post-Triassic sediments of the ophiolite zone Zermatt-Saas Fee and the associated manganese mineralizations. Eclogae Geologicae Helvetiae 74 (2), 189-205.

Beltrando, M., Manatschal, G., Mohn, G., Dal Piaz, G. V., Vitale Brovarone, A., Masini, E., 2014. Recognizing remnants of magma-poor rifted margins in high-pressure orogenic belts: The Alpine case study. Earth-Science Reviews $131,88-115$.

Beltrando, M., Rubatto, D., Manatschal, G., 2010. From passive mar995 gins to orogens: The link between ocean-continent transition zones and (ultra)high-pressure metamorphism. Geology 38 (6), 559-562.

Berezovskii, G. A., Drebushchak, V. A., Kravchenko, T. A., 2001. Lowtemperature heat capacity of pentlandite. American Mineralogist 86 (10), $1312-1313$.

Bernoulli, D., Manatschal, G., Desmurs, L., Muntener, O., 2003. Where did Gustav Steinmann see the trinity? Back to the roots of an Alpine ophiolite concept. Vol. 373 of Special Papers. Geological Society of America, USA, pp. $93-110$.

Bousquet, R., 2008. Metamorphic heterogeneities within a single HP unit: Overprint effect or metamorphic mix? Lithos 103 (1-2), 46-69. 
Cannao, E., Agostini, S., Scambelluri, M., Tonarini, S., Godard, M., 2015. $\mathrm{B}, \mathrm{Sr}$ and $\mathrm{Pb}$ isotope geochemistry of high-pressure Alpine metaperidotites monitors fluid-mediated element recycling during serpentinite dehydration in subduction melange (Cima di Gagnone, Swiss Central Alps). Geochimica Et Cosmochimica Acta 163, 80-100.

Cannat, M., Fontaine, F., Escartin, J., 2010. Serpentinization and Associated Hydrogen and Methane Fluxes at Slow Spreading Ridges. Vol. 188 of Geophysical Monograph Book Series. pp. 241-264.

Carbonin, S., Martin, S., Tumiati, S., Rossetti, P., 2015. Magnetite from the Cogne serpentinites (Piemonte ophiolite nappe, Italy). Insights into seafloor fluid-rock interaction. European Journal of Mineralogy 27 (1), 3150.

Carlson, R. L., 2001. The abundance of ultramafic rocks in Atlantic Ocean crust. Geophysical Journal International 144 (1), 37-48.

Carson, C. J., Clarke, G. L., Powell, R., 2000. Hydration of eclogite, Pam Peninsula, New Caledonia. Journal of Metamorphic Geology 18 (1), 79-90.

Castelli, D., Rostagno, C., Lombardo, B., 2002. JD-QTZ-bearing metaplagiogranite from the Monviso meta-ophiolite (Western Alps). Ofioliti 27 (2), 81-90.

Chase, M. J., 1998. NIST-JANAF Thermochemical tables: Fourth Edition. Vol. 2 of Journal of Physical and Chemical Reference Data. American Chemical Society and the American Institute of Physics for the National Institute of Standards and Technology, Gaithersburg, Maryland, U.S.A. 
Clarke, E., Glew, D., 1966. Evaluation of thermodynamic functions from

Clarke, G. L., Aitchison, J. C., Cluzel, D., 1997. Eclogites and blueschists of the Pam Peninsula, NE New Caledonia: A reappraisal. Journal of Petrology $38(7), 843-876$.

Cluzel, D., Jourdan, F., Meffre, S., Maurizot, P., Lesimple, S., 2012. The 1035 metamorphic sole of New Caledonia ophiolite: Ar-40/Ar-39, U-Pb, and geochemical evidence for subduction inception at a spreading ridge. Tectonics 31.

Dale, C. W., Burton, K. W., Pearson, D. G., Gannoun, A., Alard, O., Argles, T. W., Parkinson, I. J., 2009. Highly siderophile element behaviour accompanying subduction of oceanic crust: Whole rock and mineral-scale insights from a high-pressure terrain. Geochimica et Cosmochimica Acta 73 (5), 1394-1416.

Dean, S. M., Minshull, T. A., Whitmarsh, R. B., Louden, K. E., 2000. Deep structure of the ocean-continent transition in the southern Iberia Abyssal Plain from seismic refraction profiles: The IAM-9 transect at 40 degrees 20 ' N. Journal of Geophysical Research-Solid Earth 105 (B3), 5859-5885.

Debret, B., Andreani, M., Munoz, M., Bolfan-Casanova, N., Carlut, J., Nicollet, C., Schwartz, S., Trcera, N., 2014a. Evolution of Fe redox state in serpentine during subduction. Earth and Planetary Science Letters 400, $206-218$. 
Debret, B., Bolfan-Casanova, N., Padron-Navarta, J. A., Martin-Hernandez, F., Andreani, M., Garrido, C. J., Sanchez-Vizcaino, V. L., GomezPugnaire, M. T., Munoz, M., Trcera, N., 2015. Redox state of iron during high-pressure serpentinite dehydration. Contributions to Mineralogy and Petrology 169 (4).

Debret, B., Koga, K. T., Nicollet, C., Andreani, M., Schwartz, S., 2014b. F, $\mathrm{Cl}$ and $\mathrm{S}$ input via serpentinite in subduction zones: implications for the nature of the fluid released at depth. Terra Nova 26 (2), 96-101.

Debret, B., Millet, M.-A., Pons, M.-L., Bouihol, P., Inglis, E., Williams, H., 1060 2016. Isotopic evidence for iron mobility during subduction. Geology in press.

Delacour, A., Fruh-Green, G. L., Bernasconi, S. M., 2008. Sulfur mineralogy and geochemistry of serpentinites and gabbros of the Atlantis Massif (IODP Site U1309). Geochimica Et Cosmochimica Acta 72 (20), 51111065 5127.

Deschamps, F., Godard, M., Guillot, S., Hattori, K., 2013. Geochemistry of subduction zone serpentinites: A review. Lithos 178, 96-127.

Diella, V., Ferrario, A., Rossetti, P., 1994. The magnetite ore deposits of the Southern Aosta Valley chromitite transformed during an Alpine metamorphic event. Ofioliti 19, 247-256.

Driesner, T., 1993. Aspects of petrographic, structural and stable isotope geochemical evolution of ophicarbonate breccias from ocean-floor to subduction and uplift - an example from Chatillon, Middle Aosta valley, Ital- 
ian Alps. Schweizerische Mineralogische Und Petrographische Mitteilungen

1075

Dupuy, C., Dostal, J., Leblanc, M., 1981. Geochemistry of an ophiolitic complex from New-Caledonia. Contributions to Mineralogy and Petrology 76 (1), 77-83.

Evans, B. W., 2008. Control of the products of serpentinization by the 1080 $\mathrm{Fe}(2) \mathrm{Mg}(1)$ exchange potential of olivine and orthopyroxene. Journal of Petrology 49 (10), 1873-1887.

Evans, B. W., Dyar, M. D., Kuehner, S. M., 2012a. Implications of ferrous and ferric iron in antigorite. American Mineralogist 97 (1), 184-196.

Evans, B. W., Kuehner, S. M., Chopelas, A., 2009. Magnetite-free, yellow lizardite serpentinization of olivine websterite, Canyon Mountain complex, NE Oregon. American Mineralogist 94 (11-12), 1731-1734.

Evans, K., Elburg, M., Kamenetsky, V. S., 2012b. The oxidation state of sub-arc mantle. Geology 40, 783-786.

Evans, K., Powell, R., 2015. Metamorphic effects on the redox budget of 1090 subducted mantle lithosphere. Journal of Metamorphic Geology 33, 649670.

Evans, K., Powell, R., Holland, T., 2010. Internally consistent data for sulphur-bearing phases and application to the construction of pseudosections for mafic greenschist facies rocks in $\mathrm{Na}_{2} \mathrm{O}-\mathrm{CaO}-\mathrm{K}_{2} \mathrm{O}-\mathrm{FeO}-\mathrm{MgO}-$ 1095 $\mathrm{Al}_{2} \mathrm{O}_{3}-\mathrm{SiO}_{2}-\mathrm{CO}_{2}-\mathrm{O}-\mathrm{S}-\mathrm{H}_{2} \mathrm{O}$. Journal of Metamorphic Geology 28, 667-687. 
Evans, K., Tomkins, A., Cliff, J., Fiorentini, M. L., 2014. Insights into subduction zone sulfur recycling from isotopic analysis of eclogite-hosted sulfides. Chemical Geology 365, 1-19.

Evans, K. A., 2006. Redox decoupling and redox budgets: Conceptual tools 1100 for the study of earth systems. Geology 34 (6), 489-492.

Evans, K. A., 2012. The redox budget of subduction zones. Earth Science Reviews 113, 11-32.

Evans, K. A., Powell, R., Frost, B. R., 2013. Using equilibrium thermodynamics in the study of metasomatic alteration, illustrated by an application to serpentinites. Lithos 168, 67-84.

Fitzherbert, J. A., Clarke, G. L., Marmo, B., Powell, R., 2004. The origin and P-T evolution of peridotites and serpentinites of NE New Caledonia: prograde interaction between continental margin and the mantle wedge. Journal of Metamorphic Geology 22 (4), 327-344.

1110 Fjellvag, H., Andersen, A., 1994. Properties of $\mathrm{Ni}_{3} \mathrm{~S}_{2}$ at high temperatures. Acta Chemica Scandinavica 48 (4), 290-293.

Fontana, E., Panseri, M., Tartarotti, P., 2008. Oceanic relict textures in the Mount Avic serpentinites, Western Alps. Ofioliti 33 (2), 105-118.

Forster, M. A., Lister, G. S., Compagnoni, R., Giles, D., Hills, Q., Betts, P., 1115 Beltrando, M., Tamagno, E., 2004. Mapping of oceanic crust with "HP" to "UHP" metamorphism: The Lago di Cignana Unit, (Western Alps). Geological Society of London, Bath, pp. 279-288. 
Foustoukos, D. I., Bizimis, M., Frisby, C., Shirey, S. B., 2015. Redox controls on $\mathrm{Ni}$ - Fe - PGE mineralization and Re/Os fractionation during serpen1120 tinization of abyssal peridotite. Geochimica et Cosmochimica Acta 150, $11-25$.

Frezzotti, M. L., Huizenga, J. M., Compagnoni, R., Selverstone, J., 2014. Diamond formation by carbon saturation in C-O-H fluids during cold subduction of oceanic lithosphere. Geochimica et Cosmochimica Acta 143, 1125 68-86.

Frost, B. R., 1985. On the stability of sulfides, oxides, and native metals in serpentinite. Journal of Petrology 26 (1), 31-63.

Frost, B. R., Beard, J. S., 2007. On silica activity and serpentinization. Journal of Petrology 48 (7), 1351-1368.

${ }_{1130}$ Frost, B. R., Evans, K. A., Swapp, S. M., Beard, J. S., Mothersole, F. E., 2013. The process of serpentinization in dunite from New Caledonia. Lithos $178,24-39$.

Fry, N., Barnicoat, A. C., 1987. The tectonic implications of high-pressure metamorphism in the Western Alps. Journal of the Geological Society 144, 1135 653-659.

Gasco, I., Gattiglio, M., Borghi, A., 2013. Review of metamorphic and kinematic data from Internal Crystalline Massifs (Western Alps): PTt paths and exhumation history. Journal of Geodynamics 63, 1-19.

Ghent, E. D., Roddick, J. C., Black, P. M., 1994. Ar-40/(39)A, dating of 
white micas from the epidote to the omphacite zones, northern NewCaledonia - Tectonic implications. Canadian Journal of Earth Sciences 31 (6), 995-1001.

Gonzalez-Jimenez, J. M., Proenza, J. A., Gervilla, F., Melgarejo, J. C., Blanco-Moreno, J. A., Ruiz-Sanchez, R., Griffin, W. L., 2011. High-Cr and high-Al chromitites from the Sagua de Tanamo district, Mayari-Cristal ophiolitic massif (eastern Cuba): Constraints on their origin from mineralogy and geochemistry of chromian spinel and platinum-group elements. Lithos 125 (1-2), 101-121.

Groppo, C., Beltrando, M., Compagnoni, R., 2009. The P-T path of the ultra-high pressure Lago Di Cignana and adjoining high-pressure metaophiolitic units: insights into the evolution of the subducting Tethyan slab. Journal of Metamorphic Geology 27 (3), 207-231.

Groppo, C., Compagnoni, R., 2007. Metamorphic veins from the serpentinites of the Piemonte Zone, western Alps, Italy: a review. Periodico Di Mineralogia 76 (2-3), 127-153.

Hattori, K. H., Guillot, S., 2007. Geochemical character of serpentinites associated with high- to ultrahigh-pressure metamorphic rocks in the Alps, Cuba, and the Himalayas: Recycling of elements in subduction zones. Geochemistry Geophysics Geosystems 8.

Holland, T. J. B., Powell, R., 1991. A compensated Redlich Kwong (CORK) equation for volumes and fugacities of $\mathrm{CO} 2$ and $\mathrm{H} 2 \mathrm{O}$ in the range 1 bar to 50kB and 100-1600 C. Contrib. Mineral. Petrol. 109, 265-273. 
Holland, T. J. B., Powell, R., 1998. An internally consistent thermodynamic data set for phases of petrological interest. Journal of Metamorphic Geology 16 (3), 309-343.

Howald, R. A., 2003. The thermodynamics of tetrataenite and awaruite: A review of the Fe-Ni phase diagram. Metallurgical and Materials Transactions a-Physical Metallurgy and Materials Science 34A (9), 1759-1769.

Kelley, K. A., Cottrell, E., 2009. Water and the oxidation state of subduction 1170 zone magmas. Science 325 (5940), 605-607.

Klein, F., Bach, W., Joens, N., McCollom, T., Moskowitz, B., Berquo, T., 2009. Iron partitioning and hydrogen generation during serpentinization of abyssal peridotites from 15 degrees $\mathrm{N}$ on the Mid-Atlantic Ridge. Geochimica Et Cosmochimica Acta 73 (22), 6868-6893.

Lafay, R., Deschamps, F., Schwartz, S., Guillot, S., Godard, M., Debret, B., Nicollet, C., 2013. High-pressure serpentinites, a trap-and-release system controlled by metamorphic conditions: Example from the Piedmont zone of the western Alps. Chemical Geology 343, 38-54.

Lagabrielle, Y., 2009. Mantle exhumation and lithospheric spreading: An 1180 historical perspective from investigations in the Oceans and in the AlpsApennines ophiolites. Bollettino Della Societa Geologica Italiana 128 (2), 279-293.

Lagabrielle, Y., Brovarone, A. V., Ildefonse, B., 2015. Fossil oceanic core complexes recognized in the blueschist metaophiolites of Western Alps and 1185 Corsica. Earth-Science Reviews 141, 1-26. 
Lee, C. T. A., Leeman, W. P., Canil, D., Li, Z. X. A., 2005. Similar V/Sc systematics in MORB and arc basalts: Implications for the oxygen fugacities of their mantle source regions. Journal of Petrology 46 (11), 2313-2336.

Lefeldt, M., Ranero, C. R., Grevemeyer, I., 2012. Seismic evidence of tec1190 tonic control on the depth of water influx into incoming oceanic plates at subduction trenches. Geochemistry Geophysics Geosystems 13.

Li, X. P., Rahn, M., Bucher, K., 2004. Serpentinites of the Zermatt-Saas ophiolite complex and their texture evolution. Journal of Metamorphic Geology 22 (3), 159-177.

Li, X. P., Rahn, M., Bucher, K., 2008. Eclogite facies metarodingites - phase relations in the system $\mathrm{SiO}_{2}-\mathrm{Al}_{2} \mathrm{O}_{3}-\mathrm{Fe}_{2} \mathrm{O}_{3}-\mathrm{FeO}-\mathrm{MgO}-\mathrm{CaO}-\mathrm{CO}_{2}-\mathrm{H}_{2} \mathrm{O}$ : an example from the Zermatt-Saas ophiolite. Journal of Metamorphic Geology $26(3), 347-364$.

Mallmann, G., O’Neill, H. S. C., 2009. The crystal/melt partitioning of V during mantle melting as a function of oxygen fugacity compared with some other elements (Al, P, Ca, Sc, Ti, Cr, Fe, Ga, Y, Zr and Nb). Journal of Petrology 50 (9), 1765-1794.

Manatschal, G., Muntener, O., 2009. A type sequence across an ancient magma-poor ocean-continent transition: the example of the western Alpine Tethys ophiolites. Tectonophysics 473 (1-2), 4-19.

Messiga, B., Kienast, J. R., Rebay, G., Riccardi, M. P., Tribuzio, R., 1999. Cr-rich magnesiochloritoid eclogites from the Monviso ophiolites (Western Alps, Italy). Journal of Metamorphic Geology 17 (3), 287-299. 
Messiga, B., Scambelluri, M., 1991. Retrograde P-T-t path for the Voltri1210 Massif eclogites (Ligurian Alps, Italy) - some tectonic implications. Journal of Metamorphic Geology 9 (1), 93-109.

Mottana, A., Bocchio, R., 1975. Superferric eclogites of Voltri group (Pennidic belt, Appenines). Contributions to Mineralogy and Petrology 49 (3), 201-210.

Mungall, J. E., 2002. Roasting the mantle: Slab melting and the genesis of major Au and Au-rich Cu deposits. Geology 30 (10), 915-918.

Muntener, O., Hermann, J., 1996. The Val Malenco lower crust - Upper mantle complex and its field relations (Italian Alps). Schweizerische Mineralogische Und Petrographische Mitteilungen 76 (3), 475-500.

Muntener, O., Manatschal, G., Desmurs, L., Pettke, T., 2010. Plagioclase peridotites in Ocean-Continent Transitions: Refertilized mantle domains generated by melt stagnation in the shallow mantle Lithosphere. Journal of Petrology 51 (1-2), 255-294.

Naif, S., Key, K., Constable, S., Evans, R. L., 2015. Water-rich bending ${ }_{1225}$ faults at the Middle America Trench. Geochemistry Geophysics Geosystems 16 (8), 2582-2597.

Newton, R. C., Manning, C. E., 2005. Solubility of anhydrite, $\mathrm{CaSO}_{4}$, in $\mathrm{NaCl}-\mathrm{H}_{2} \mathrm{O}$ solutions at high pressures and temperatures: Applications to fluid-rock interaction. Journal of Petrology 46 (4), 701-716. 
Nozaka, T., 2003. Compositional heterogeneity of olivine in thermally metamorphosed serpentinite from Southwest Japan. American Mineralogist $88(8-9), 1377-1384$.

Oufi, O., Cannat, M., Horen, H., 2002. Magnetic properties of variably serpentinized abyssal peridotites. Journal of Geophysical Research-Solid 1235

Parise, J. B., 1980. Structure of hazelwoodite $\left(\mathrm{Ni}_{3} \mathrm{~S}_{2}\right)$. Acta Crystallographica Section B-Structural Science 36 (MAY), 1179-1180.

Parkinson, I., Arculus, R. J., 1999. The redox state of subduction zones: insights from arc-peridotites. Chemical Geology 160, 409-423.

Peretti, A., Dubessy, J., Mullis, J., Frost, B. R., Trommsdorff, V., 1992. Highly reducing conditions during Alpine metamorphism of the Malenco peridotite (Sondrio, Northern Italy) indicated by mineral paragenesis and fluid inclusions. Contributions to Mineralogy and Petrology 112 (2-3), 329340.

1245

Pirard, C., Hermann, J., O’Neill, H. S., 2013. Petrology and feochemistry of the crust-mantle boundary in a nascent arc, Massif du Sud Ophiolite, New Caledonia, SW Pacific. Journal of Petrology 54 (9), 1759-1792.

Plyasunov, A. V., 2015. Correlation and prediction of thermodynamic properties of nonelectrolytes at infinite dilution in water over very wide tem1250 perature and pressure ranges (2000 K and $10 \mathrm{GPa}$ ). Geochimica Et Cosmochimica Acta 168, 236-260. 
Rahn, M. K., Bucher, H., 1998. Titanian clinohumite formation in the Zermatt-Saas ophiolites, Central Alps. Mineralogy and Petrology 64 (14), 1-13.

Rajamani, V., Prewitt, C. T., 1975. Thermal expansion of pentandite structure. American Mineralogist 60 (1-2), 39-48.

Ranero, C. R., Sallares, V., 2004. Geophysical evidence for hydration of the crust and mantle of the Nazca plate during bending at the north Chile trench. Geology $32(7), 549-552$.

Rebay, G., Spalla, M. I., Zanoni, D., 2012. Interaction of deformation and metamorphism during subduction and exhumation of hydrated oceanic mantle: Insights from the Western Alps. Journal of Metamorphic Geology $30(7), 687-702$.

Reddy, S. M., Wheeler, J., Cliff, R. A., 1999. The geometry and timing of orogenic extension: an example from the Western Italian Alps. Journal of Metamorphic Geology 17 (5), 573-589.

Robie, R., Hemingway, B., 1995. Thermodynamic properties of minerals and related substances at $298.15 \mathrm{~K}$ and 1 bar $\left(10^{5}\right.$ Pascals) pressure and at higher temperatures. USGS Bulletin B 2131. USGS, USA.

Scambelluri, M., Pettke, T., Rampone, E., Godard, M., Reusser, E., 2014. Petrology and trace element budgets of high-pressure peridotites indicate subduction dehydration of serpentinized mantle (Cima di Gagnone, Central Alps, Switzerland). Journal of Petrology 55 (3), 459-498. 
Scambelluri, M., Piccardo, G. B., Philippot, P., Robbiano, A., Negretti, L.,

1997. High salinity fluid inclusions formed from recycled seawater in deeply subducted alpine serpentinite. Earth and Planetary Science Letters 148 (34), 485-499.

Schwartz, S., Lardeaux, J. M., Guillot, S., Tricart, P., 2000. The diversity of eclogitic metamorphism in the Monviso ophiolitic complex, western Alps, Italy. Geodinamica Acta 13 (2-3), 169-188.

Schwarzenbach, E. M., Fruh-Green, G. L., Bernasconi, S. M., Alt, J. C., Plas, A., 2013. Serpentinization and carbon sequestration: A study of two ancient peridotite-hosted hydrothermal systems. Chemical Geology 351, $115-133$.

Schwarzenbach, E. M., Fruh-Green, G. L., Bernasconi, S. M., Alt, J. C., Shanks, W. C., Gaggero, L., Crispini, L., 2012. Sulfur geochemistry of peridotite-hosted hydrothermal systems: Comparing the Ligurian ophiolites with oceanic serpentinites. Geochimica Et Cosmochimica Acta 91, $283-305$.

Schwarzenbach, E. M., Gazel, E., Caddick, M. J., 2014. Hydrothermal processes in partially serpentinized peridotites from Costa Rica: evidence from native copper and complex sulfide assemblages. Contributions to Mineralogy and Petrology 168 (5).

Skelton, A., Whitmarsh, R., Arghe, F., Crill, P., Koyi, H., 2005. Constraining the rate and extent of mantle serpentinization from seismic and petrologi- 
cal data: implications for chemosyntesis and tectonic processes. Geofluids $5(3), 153-164$.

Sowa, H., Ahsbahs, H., Schmitz, W., 2004. X-ray diffraction studies of millerite NiS under non-ambient conditions. Physics and Chemistry of Minerals $31(5), 321-327$.

Spandler, C., Hartmann, J., Faure, K., Mavrogenes, J. A., Arculus, R. J., 2008. The importance of talc and chlorite "hybrid" rocks for volatile recycling through subduction zones; evidence from the high-pressure subduction melange of New Caledonia. Contributions to Mineralogy and Petrology $155(2), 181-198$.

Spandler, C., Pettke, T., Rubatto, D., 2011. Internal and external fluid sources for eclogite-facies vveins in the Monviso meta-ophiolite, Western Alps: Implications for fluid flow in subduction zones. Journal of Petrology $52(6), 1207-1236$.

1310 Suleimenov, O. M., Krupp, R. E., 1994. Solubility of hydrogen sulfide in pure water and in $\mathrm{NaCl}$ solutions, from 20 degrees $\mathrm{C}$ to 320 degrees $\mathrm{C}$ and at saturation pressures. Geochimica Et Cosmochimica Acta 58 (11), 2433-2444.

Tomkins, A., Evans, K., 2015. Separate zones of sulfate and sulfide release 1315 from subducted mafic ocean crust. Earth and Planetary Science Letters 428, 73-83.

Trommsdorff, V., Piccardo, G. B., Montrasio, A., 1993. From magmatism through metamorphism to sea-floor emplacement of subcontinental Adria 
lithosphere during pre-Alpine rifting (Malenco, Italy). Schweizerische Mineralogische Und Petrographische Mitteilungen 73 (2), 191-203.

Trommsdorff, V., Sanchez-Vizcaino, V. L., Gomez-Pugnaire, M. T., Muntener, O., 1998. High pressure breakdown of antigorite to spinifextextured olivine and orthopyroxene, SE Spain. Contributions to Mineralogy and Petrology 132 (2), 139-148.

Tumiati, S., Godard, G., Martin, S., Malaspina, N., Poli, S., 2015. Ultraoxidized rocks in subduction melanges? Decoupling between oxygen fugacity and oxygen availability in a Mn-rich metasomatic environment. Lithos 226, 116-130.

Ulmer, P., Trommsdorff, V., 1995. Serpentine stability to mantle depths and subduction-related magmatism. Science 268 (5212), 858-861.

Vignaroli, G., Rossetti, F., Bouybaouene, M., Massonne, H. J., Theye, T., Faccenna, C., Funiciello, R., 2005. A counter-clockwise P-T path for the Voltri Massif eclogites (Ligurian Alps, Italy). Journal of Metamorphic Geology $23(7), 533-555$.

1335 Vitale Brovarone, A., Picatto, M., Beyssac, O., Lagabrielle, Y., Castelli, D., 2014. The blueschist-eclogite transition in the Alpine chain: P-T paths and the role of slow-spreading extensional structures in the evolution of HP-LT mountain belts. Tectonophysics 615, 96-121.

Waldner, P., Pelton, A. D., 2004. Thermodynamic modeling of the Ni-S system. Zeitschrift Fur Metallkunde 95 (8), 672-681. 
Yu, Y. G., Ross, N. L., 2011. Vibrational and thermodynamic properties of $\mathrm{Ni}_{3} \mathrm{~S}_{2}$ polymorphs from first-principles calculations. Physics and Chemistry of Minerals 38 (3), 241-249.

Zucchetti, S., Mastrangelo, F., Rossetti, P., Sandrone, R., 1988. Serpentiniza1345 tion and metamorphism: their relationships with metallogeny in some ophiolitic ultramafics from the Alps. Zuffar Days Symposium in Honor of Pero Zuffardi, University of Cagliari, Cagliari, Oct 10-15, 137-159. 


\section{FIGURE CAPTIONS}

Figure 1: Sample localities (a) New Caledonia, after Fitzherbert et al. 1350 (2004); (b) the Zermatt Saas Zone in the Western Alps, after Barnicoat and Fry (1986).

Figure 2: Texturally late magnetite in (a) New Caledonia sample NC0760; (b) Zermatt Saas Zone sample LC-015; (c) Zermatt Saas Zone sample PF-001 - here the large opaque grain is magnetite rimmed with ilmenite; (d) Zermatt Saas Zone sample GSZ11-a.

Figure 3: magnetite relationships: $(\mathrm{a}, \mathrm{b})$ details of different magnetite generations and their relationship with awaruite in NC07-60; (c) pentlandite overgrown by magnetite in GSZ-11a; (d) heazlewoodite and pentlandite overgrown by magnetite with millerite in the matrix in GSZ-11a.

Figure 4: alloys: (a) intergrown pentlandite and awaruite with magnetite and serpentine in NC09-01a; (b) native copper in NC09-01a; (c) Ruthenium alloy with laurite $\left(\mathrm{RuS}_{2}\right)$ in NC09-01a; (d) intergrown awaruite and magnetite in NC07-60;

Figure 5: Qualitative $a \mathrm{H}_{2}-a \mathrm{H}_{2} \mathrm{~S}$ diagram to illustrate relative conditions of stability for the Alpine and New Caledonian samples. After Klein et al. (2009). Abbreviations: ZS: Zermatt Saas Zone; a: activity; aw: awaruite; hz: heazlewoodite; hm: hematite; mi: millerite; mt: magnetite; pn: pentlandite; po: pyrrhotite; pyr: pyrite; vs: vaesite. Marked buffers are: AMPZ: awaruite-magnetite-pentlandite- 

pyrite; and FMQ: quartz-fayalite-magnetite.

Figure 6: Quantitative $\mathrm{aO}_{2}-\mathrm{aS}_{2}$ diagrams (a) $0.5 \mathrm{GPa}$; (b) 2 GPa. Abbreviations: ZS: Zermatt Saas Zone; a: activity; aw: awaruite; hz: heazlewoodite; hm: hematite; mi: millerite; mt: magnetite; pn: pent1375 landite; po: pyrrhotite; pyr: pyrite; vs: vaesite. Marked buffers are: AMPZ: awaruite--magnetite-pentlandite-heazlewoodite; PPM: pyritepyrrhotite-magnetite, HMP: hematite-magnetite-pyrite; and FMQ: quartzfayalite-magnetite. 
Table 1: Details of sampled locations, pressures, temperatures and literature descriptions

\begin{tabular}{llllll}
\hline & NC09-1a & NC07-60 & PF-001 & GSZ-11a & LC-015 \\
\hline Reference & 1 & 2 & 3 & 4 & 5 \\
GPS Zone & $58 \mathrm{~K}$ & $58 \mathrm{~K}$ & $32 \mathrm{~T}$ & $32 \mathrm{~T}$ & $32 \mathrm{~T}$ \\
$\mathrm{mE}$ & 0694332 & 0463563 & 0410417 & 0405623 & 0391613 \\
$\mathrm{mN}$ & 7549631 & 7737418 & 5096587 & 5081001 & 5080719 \\
Peak pressure (GPa) & 0.2 & 1.6 & $1.7-2$ & $1.8-2$ & $2.7-2.8$ \\
Peak temperature $\left({ }^{\circ} \mathrm{C}\right)$ & $<300$ & $500-600$ & $550-600$ & $550-650$ & 600 \\
\hline References: 1: & Frost et al. $\mid(2013) ; 2:$ & Fitzherbert et al. $(2004) ; 3:$ & Fry and Barnicoat & $(1987) ;$ \\
4: Gasco et al. & $(2013) ; 5:$ Groppo et al. $(2009)$ \\
Co-ordinates are given in & UTM/UPS format relative to the WGS84 map datum \\
\hline
\end{tabular}

\section{Tables}


Table 2: Sources of parameters for thermodynamic calculations

\begin{tabular}{|c|c|c|c|c|c|c|c|c|c|}
\hline & $\Delta H_{\mathrm{f}}^{\ominus}$ & $S$ & $V$ & $\mathrm{C}_{\mathrm{p}}$ & $a_{\mathrm{oi}}$ & $\kappa_{298}$ & $T_{\lambda}$ & $S_{\max }$ & $V_{\max }$ \\
\hline Awaruite & H03 & H03 & A90 & 1 & 1 & 1 & 1 & 1 & 1 \\
\hline Heazlewoodite & RH95 & RH95 & P80 & RH95 & JH94 & YR11 & n.a. & n.a. & n.a. \\
\hline Magnetite & HP98 & HP98 & HP98 & HP98 & HP98 & HP98 & HP98 & HP98 & HP98 \\
\hline Millerite & RH95 & RH95 & RH95 & RH95 & S04 & S04 & n.a. & n.a. & n.a. \\
\hline Pentlandite & RH95 & RH95 & RH95 & B01 & RP75 & n.a. & n.a. & n.a. & n.a. \\
\hline Pyrite & E11 & E11 & E11 & E11 & E11 & E11 & E11 & E11 & E11 \\
\hline Pyrrhotite & E11 & E11 & E11 & E11 & E11 & E11 & E11 & E11 & E11 \\
\hline Vaesite & C98 & C98 & C66 & WP04 & 2 & 2 & n.a. & n.a. & n.a. \\
\hline $\mathrm{H}_{2} \mathrm{O}$ & HP98 & HP98 & HP98 & HP98 & HP98 & HP98 & HP98 & HP98 & HP98 \\
\hline $\mathrm{H}_{2}$ & HP98 & HP98 & HP98 & HP98 & HP98 & HP98 & HP98 & HP98 & HP98 \\
\hline $\mathrm{H}_{2} \mathrm{~S}$ & E11 & E11 & E11 & E11 & E11 & E11 & E11 & E11 & E11 \\
\hline $\mathrm{O}_{2}$ & HP98 & HP98 & HP98 & HP98 & HP98 & HP98 & HP98 & HP98 & HP98 \\
\hline $\mathrm{S}_{2}$ & E11 & E11 & E11 & E11 & E11 & E11 & E11 & E11 & E11 \\
\hline$\Delta H_{\mathrm{f}}^{\ominus}$ & \multicolumn{9}{|c|}{ Enthalpy of formation at standard state } \\
\hline$S$ & \multicolumn{9}{|c|}{ Entropy at standard state } \\
\hline$V$ & \multicolumn{9}{|c|}{ Volume under standard state conditions } \\
\hline $\mathrm{C}_{P, a-d}$ & \multicolumn{9}{|c|}{ Maier-Kelley heat capacity coefficients } \\
\hline$a_{o i}$ & \multicolumn{9}{|c|}{ Thermal expansion coefficient } \\
\hline$\kappa_{298}$ & \multicolumn{9}{|c|}{ Bulk modulus } \\
\hline$T_{\lambda}$ & \multicolumn{9}{|c|}{ Critical temperature for order-disorder phase transitions } \\
\hline$S_{\max }$ & \multicolumn{9}{|c|}{ Maximum entropy of disorder } \\
\hline$V_{\max }$ & \multicolumn{9}{|c|}{ Maximum volume of disorder } \\
\hline B01 & \multicolumn{9}{|c|}{ Berezovskii et al. (2001) } \\
\hline C98 & \multicolumn{9}{|c|}{ Chase $(1998)$} \\
\hline C66 & \multicolumn{9}{|c|}{ Clarke and Glew (1966) } \\
\hline E11 & \multicolumn{9}{|c|}{ Evans et al. $(2010)$} \\
\hline JH94 & \multicolumn{9}{|c|}{ Fjellvag and Andersen (1994) } \\
\hline H03 & \multicolumn{9}{|c|}{ Howald (2003) } \\
\hline HP98 & \multicolumn{9}{|c|}{ Holland and Powell (1998) } \\
\hline P80 & \multicolumn{9}{|c|}{ Parise $(1980)$} \\
\hline RP75 & \multicolumn{9}{|c|}{ Rajamani and Prewitt 1975) } \\
\hline RH95 & \multicolumn{9}{|c|}{ Robie and Hemingway (1995) } \\
\hline S04 & \multicolumn{9}{|c|}{ Sowa et al. $(2004)$} \\
\hline WP04 & \multicolumn{9}{|c|}{ Waldner and Pelton (2004) } \\
\hline YR11 & \multicolumn{9}{|c|}{ 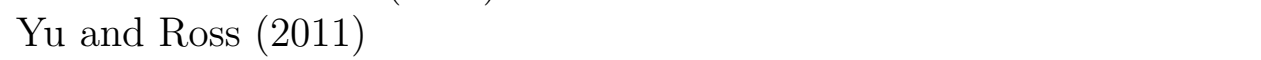 } \\
\hline 1 & \multirow{2}{*}{\multicolumn{9}{|c|}{$\begin{array}{l}\text { Taken from weighted average of properties for } \mathrm{Fe} \text { and Ni in HP98 } \\
\text { Values for pyrite used }\end{array}$}} \\
\hline 2 & & & & & & & & & \\
\hline
\end{tabular}


Table 3: Feature mapping results

\begin{tabular}{|c|c|c|c|c|c|}
\hline Percentages * & NC09-1a & NC07-60 & PF-001 & GSZ-11a & LC-015 \\
\hline native $\mathrm{Cu}$ & 1.2 & - & - & - & - \\
\hline awaruite & 3.7 & 17 & - & $0.7 \mathrm{E}$ & - \\
\hline magnetite & 66 & 82 & 14 & 45 & 73 \\
\hline hematite & - & - & - & - & - \\
\hline pyrrhotite & - & - & - & - & - \\
\hline pyrite & - & - & 1 & - & 1 \\
\hline barite & - & - & - & - & 24 \\
\hline heazlewoodite & 2 & - & & $43 \mathrm{E}$ & - \\
\hline pentlandite & 26 & 1 & - & $8 \mathrm{E}$ & - \\
\hline millerite & $0.6 \mathrm{~L}$ & - & $\begin{array}{l}- \\
-\end{array}$ & 4 & - \\
\hline ilmenite & - & - & 17 & - & - \\
\hline zircon & - & - & $67 \mathrm{~L}$ & - & - \\
\hline monazite & - & - & $0.1 \mathrm{~L}$ & - & 1 \\
\hline sphalerite & - & - & 0.3 & - & - \\
\hline chalcopyrite & - & - & 1.3 & - & - \\
\hline galena & - & - & - & - & 1 \\
\hline PGM & $\mathrm{T}$ & - & - & - & - \\
\hline Total features & 1083 & 96 & 611 & 866 & 3637 \\
\hline Non-opaque minerals & $\begin{array}{l}\text { ol, opx, cpx } \\
\text { liz, chl }\end{array}$ & $\begin{array}{l}\text { ol } \\
\text { atg, br }\end{array}$ & $\begin{array}{l}\text { ap, zircon } \\
\text { chl, atg, ta }\end{array}$ & $\begin{array}{l}\text { ol } \\
\text { atg, chl }\end{array}$ & $\begin{array}{l}\mathrm{cpx} \\
\text { atg, talc }\end{array}$ \\
\hline $\begin{array}{l}\text { *Percentages refers to } \\
\text { Abbreviations: E: Ear } \\
\text { ap: apatite; atg: antig } \\
\text { chl: chlorite; liz: lizar }\end{array}$ & $\begin{array}{l}\text { the percentag } \\
\text { ly; L: Late; T } \\
\text { orite; br: bru } \\
\text { lite; ol: olivin }\end{array}$ & $\begin{array}{l}\text { of the to } \\
\text { Trace }(< \\
\text { ite; cpx: c } \\
\text {; opx: ort }\end{array}$ & $\begin{array}{l}\text { al number of } \\
\text { O.1\%); PGM } \\
\text { inopyroxene; } \\
\text { opyroxene; } t\end{array}$ & $\begin{array}{l}\text { features ( } \\
\text { Platinum g } \\
\text { : talc }\end{array}$ & $\begin{array}{l}\text { otal feature } \\
\text { roup minera }\end{array}$ \\
\hline
\end{tabular}


Table 4: Results of whole rock analysis

\begin{tabular}{lllllll}
\hline Element & Unit & NC09-01 & NC07-60 & PF001 & GSZ-11 & LC015 \\
\hline $\mathrm{SiO}_{2}$ & wt $\%$ & 38.22 & 40.40 & 37.40 & 40.77 & 37.67 \\
$\mathrm{TiO}_{2}$ & wt $\%$ & $<0.01$ & $<0.01$ & 0.89 & 0.01 & 0.09 \\
$\mathrm{Al}_{2} \mathrm{O}_{3}$ & wt $\%$ & 0.23 & 0.59 & 7.23 & 1.26 & 2.03 \\
$\mathrm{Fe}_{2} \mathrm{O}_{3}$ (tot) & wt $\%$ & 7.69 & 6.67 & 11.21 & 8.40 & 11.51 \\
$\mathrm{FeO}$ & wt $\%$ & 4.32 & 3.40 & 6.19 & 4.05 & 3.62 \\
$\mathrm{MgO}$ & wt $\%$ & 41.77 & 39.05 & 33.49 & 40.86 & 36.40 \\
$\mathrm{MnO}$ & wt $\%$ & 0.11 & 0.10 & 0.11 & 0.16 & 0.14 \\
$\mathrm{CaO}$ & wt $\%$ & 0.25 & $<0.01$ & 0.67 & 1.10 & 0.04 \\
$\mathrm{Na}$ & wt $\%$ & 0.05 & 0.02 & 0.07 & 0.05 & 0.09 \\
& & & & & & \\
$\mathrm{C}$ & wt $\%$ & 0.088 & 0.080 & 0.050 & 0.05 & 0.040 \\
$\mathrm{P}$ & wt $\%$ & $<0.001$ & 0.002 & 0.009 & $<0.002$ & $<0.004$ \\
$\mathrm{~S}$ & wt $\%$ & 0.005 & $<0.002$ & $<0.01$ & 0.01 & 0.020 \\
& & & & & & \\
$\mathrm{LOI}$ & wt $\%$ & 9.95 & 12.22 & 10.31 & 7.36 & 10.72 \\
$\mathrm{Zn}$ & & & & & & \\
$\mathrm{V}$ & ppm & $<50$ & 51 & 53 & 45 & 55 \\
$\mathrm{Cr}$ & ppm & $<50$ & 31 & 136 & 21 & 63 \\
$\mathrm{Co}$ & ppm & 1198 & 2517 & 118 & 1978 & 2734 \\
$\mathrm{Ni}$ & ppm & 107 & 109 & 101 & 119 & 117 \\
$\mathrm{Fe}(\mathrm{III}) / \mathrm{Fe}($ tot $)$ & & 0.38 & 0.43 & 0.39 & 0.46 & 0.65 \\
\hline \hline
\end{tabular}


1380 11. Figures 

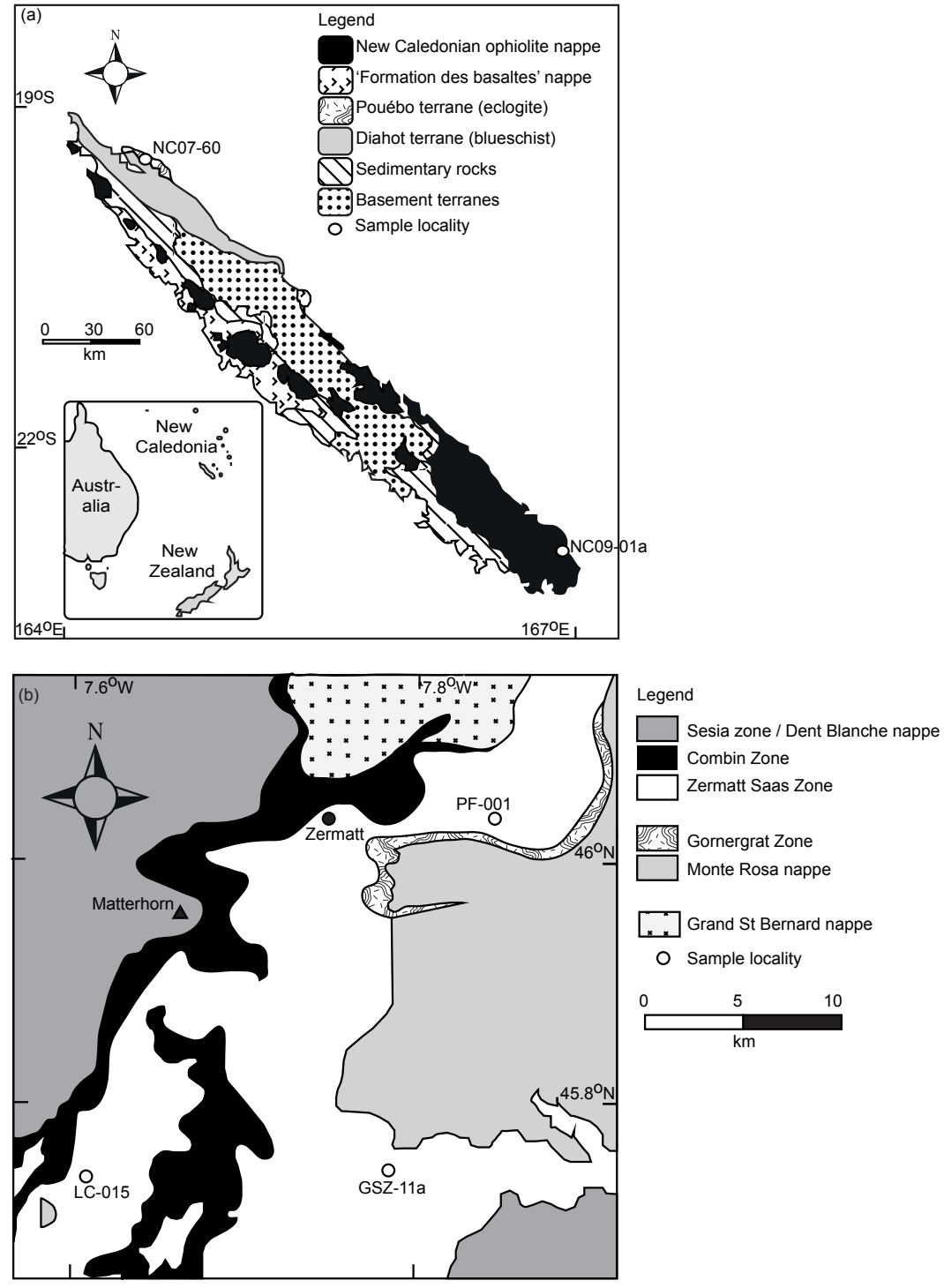

Figure 1: 685 columns 

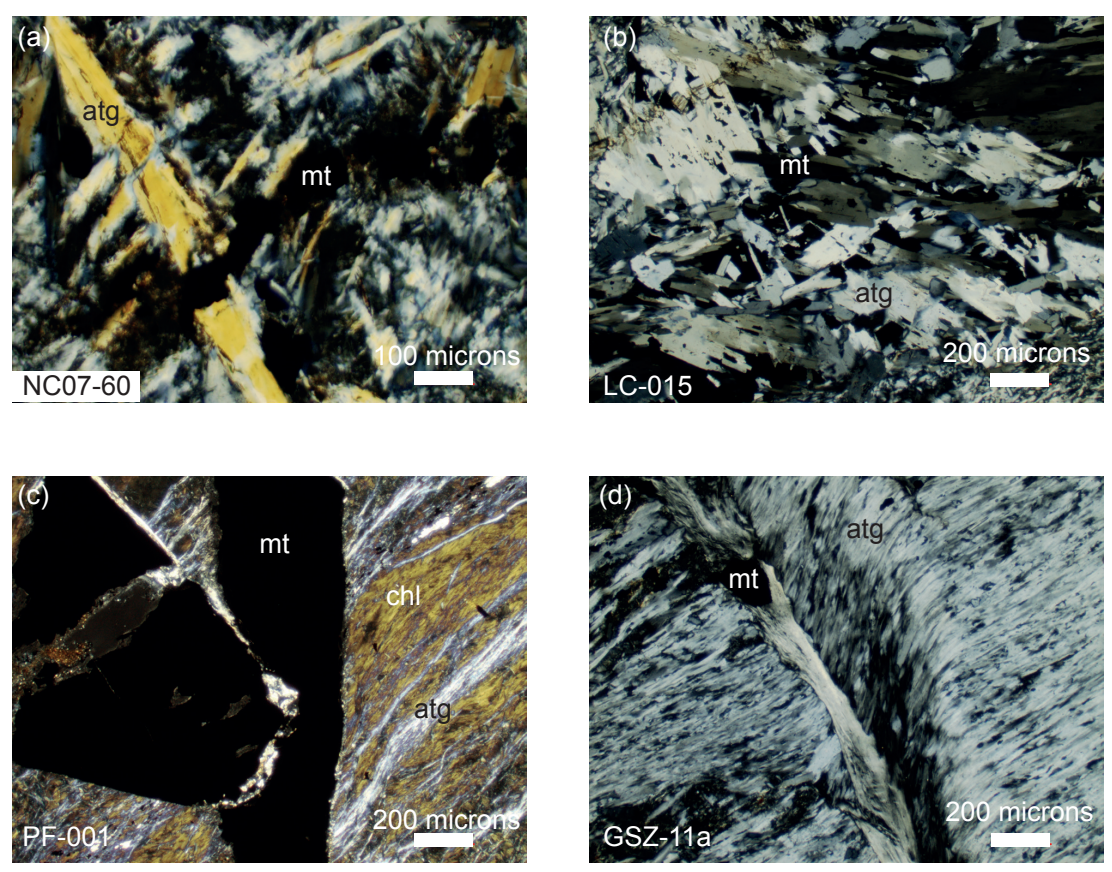

Figure 2: 2 columgg, black and white 

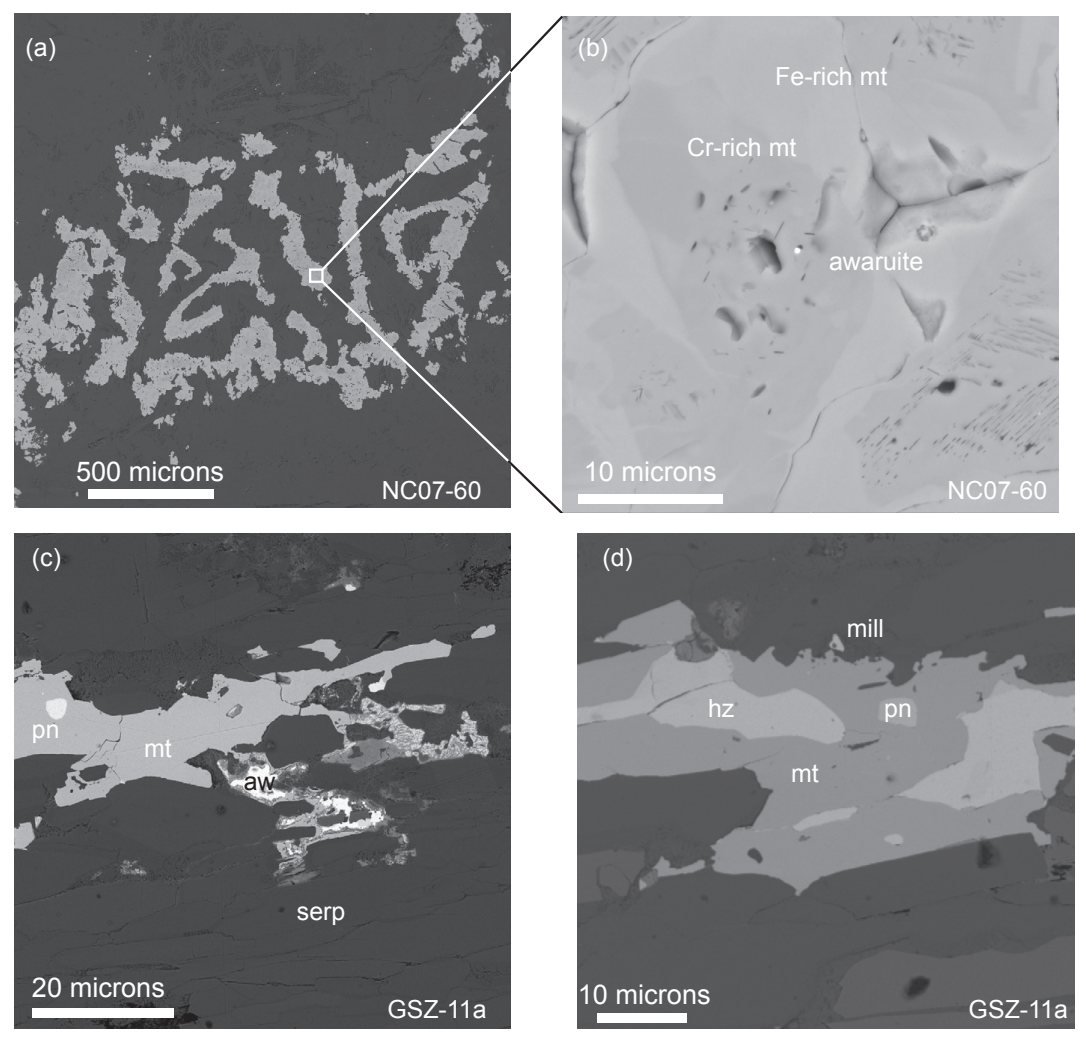

Figure 3: 2 colump丹, black and white 

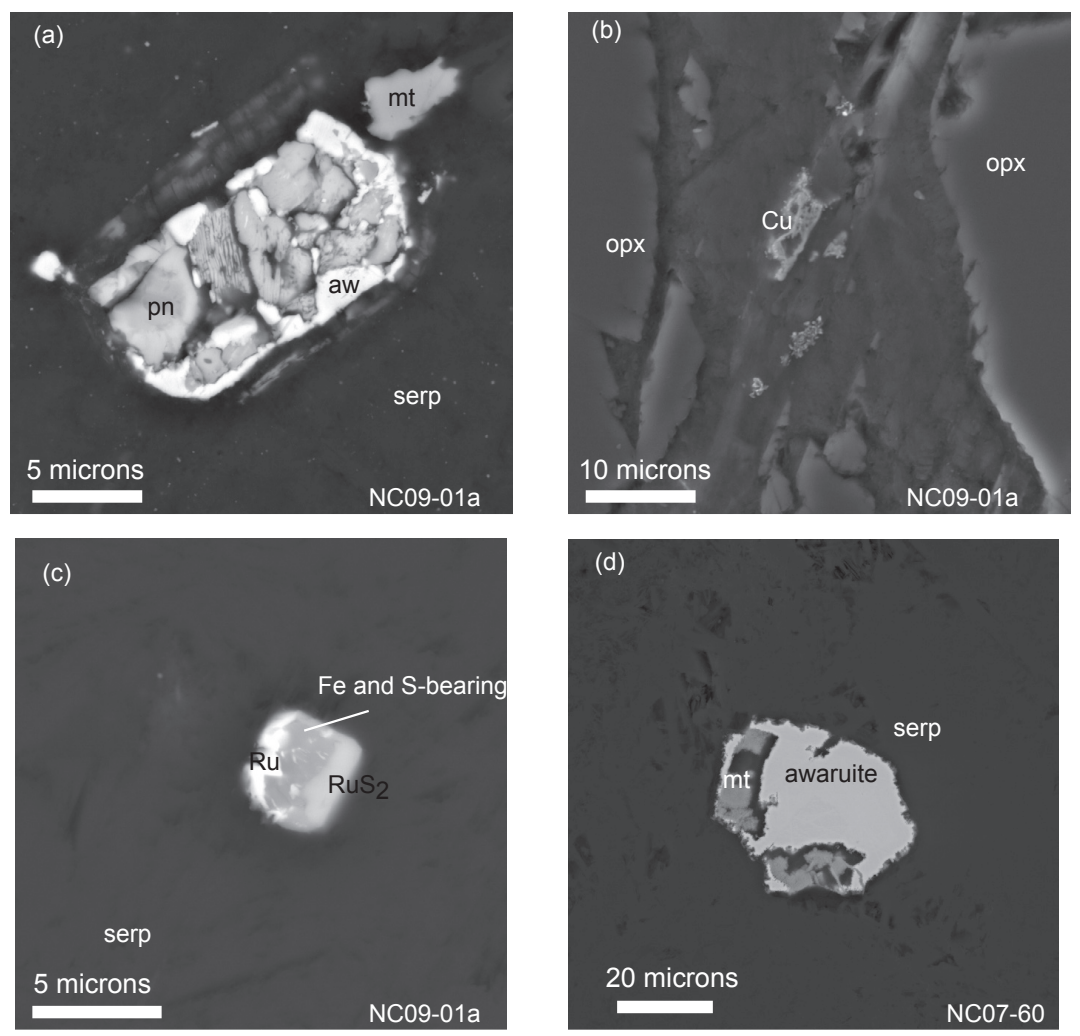

Figure 4: 2 columplp, black and white 


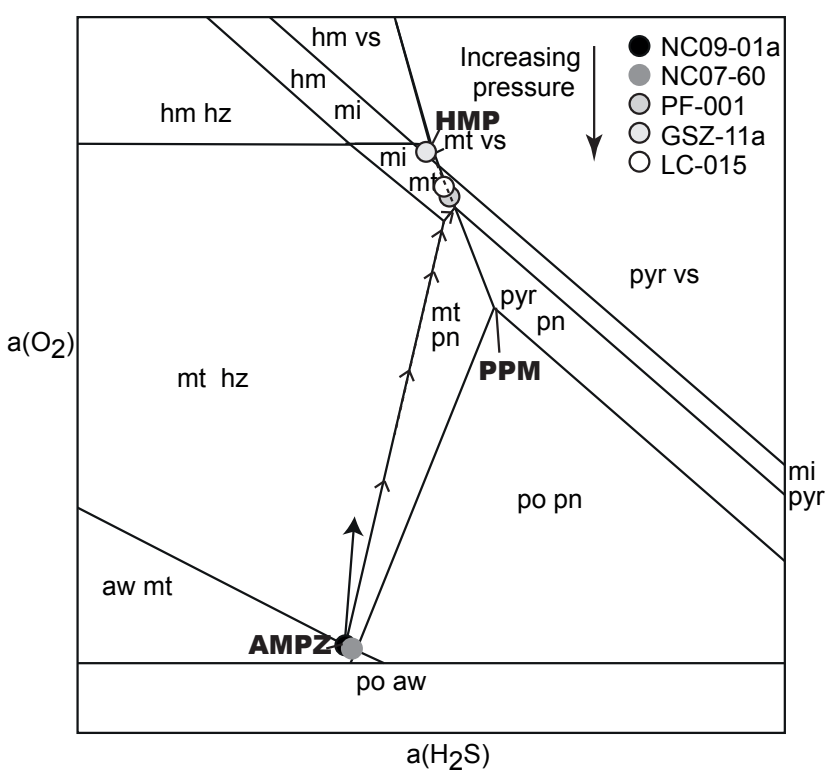

Figure 5: 2 columps, black and white 

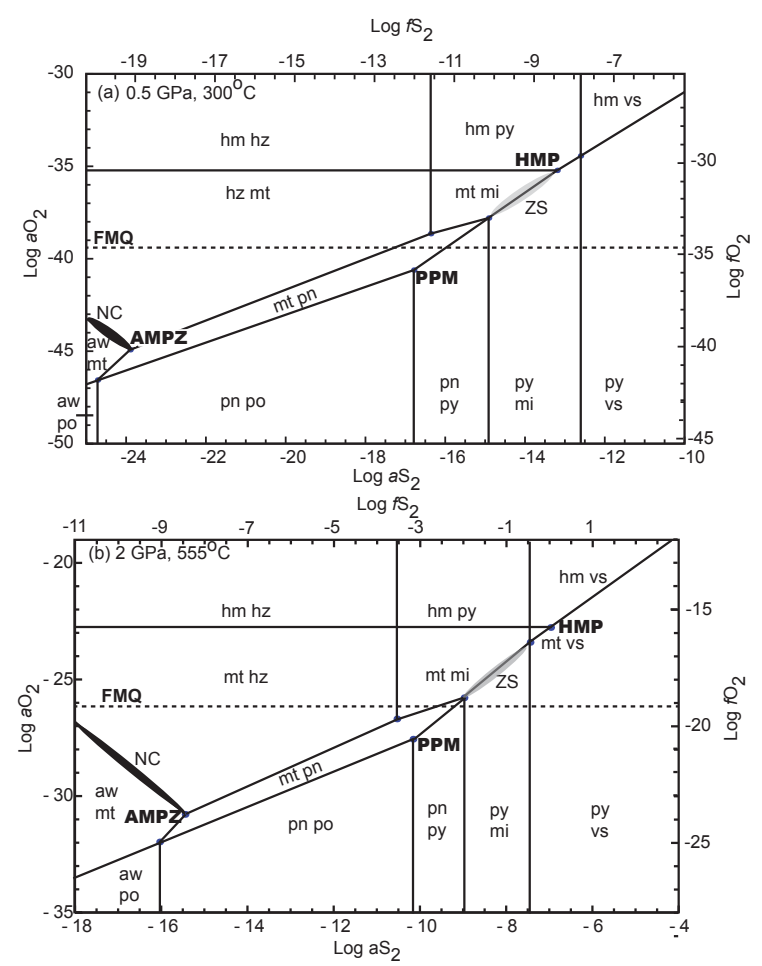

Figure 6: 2 columps, black and white 
12. Supplementary Information 


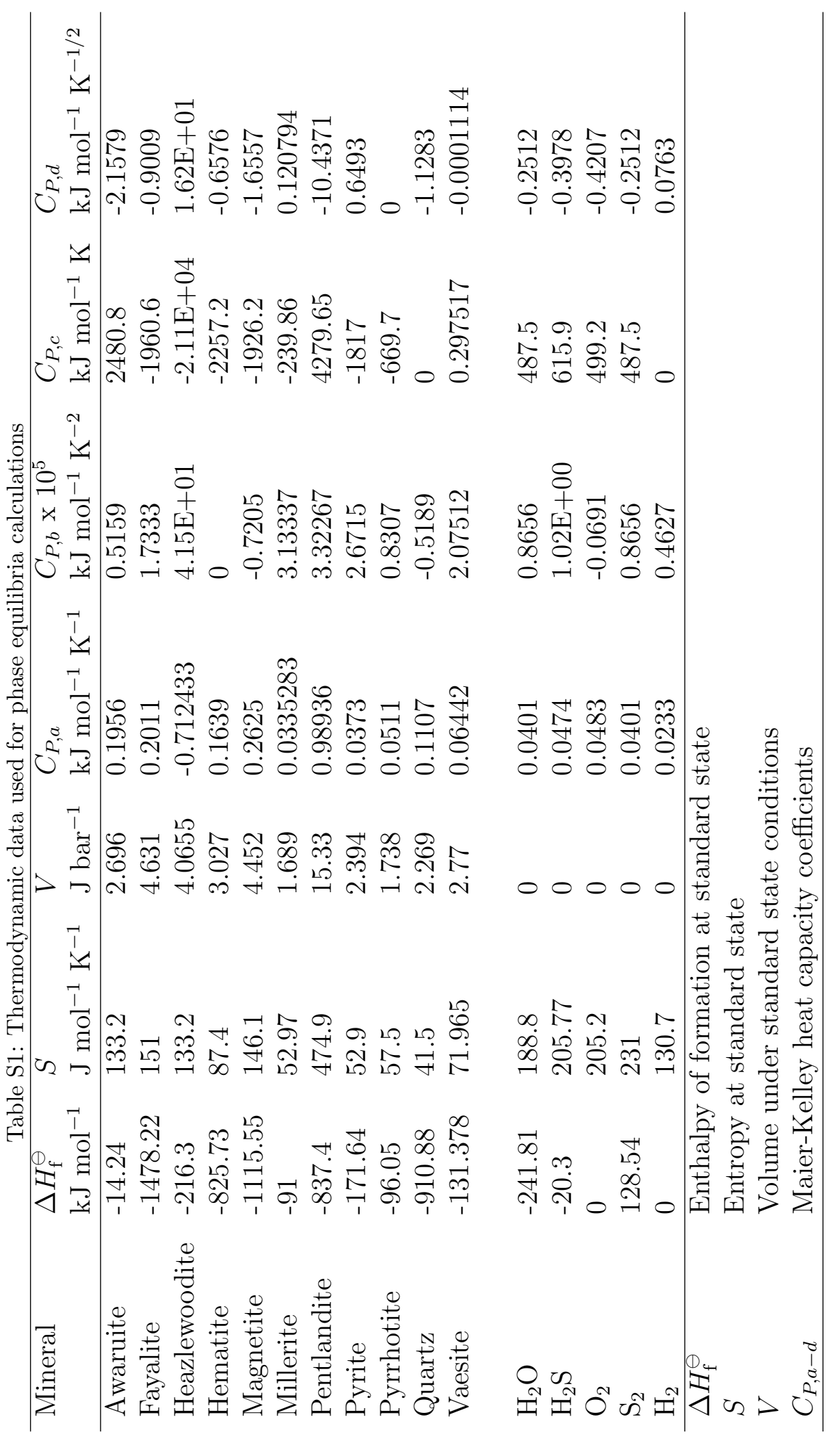




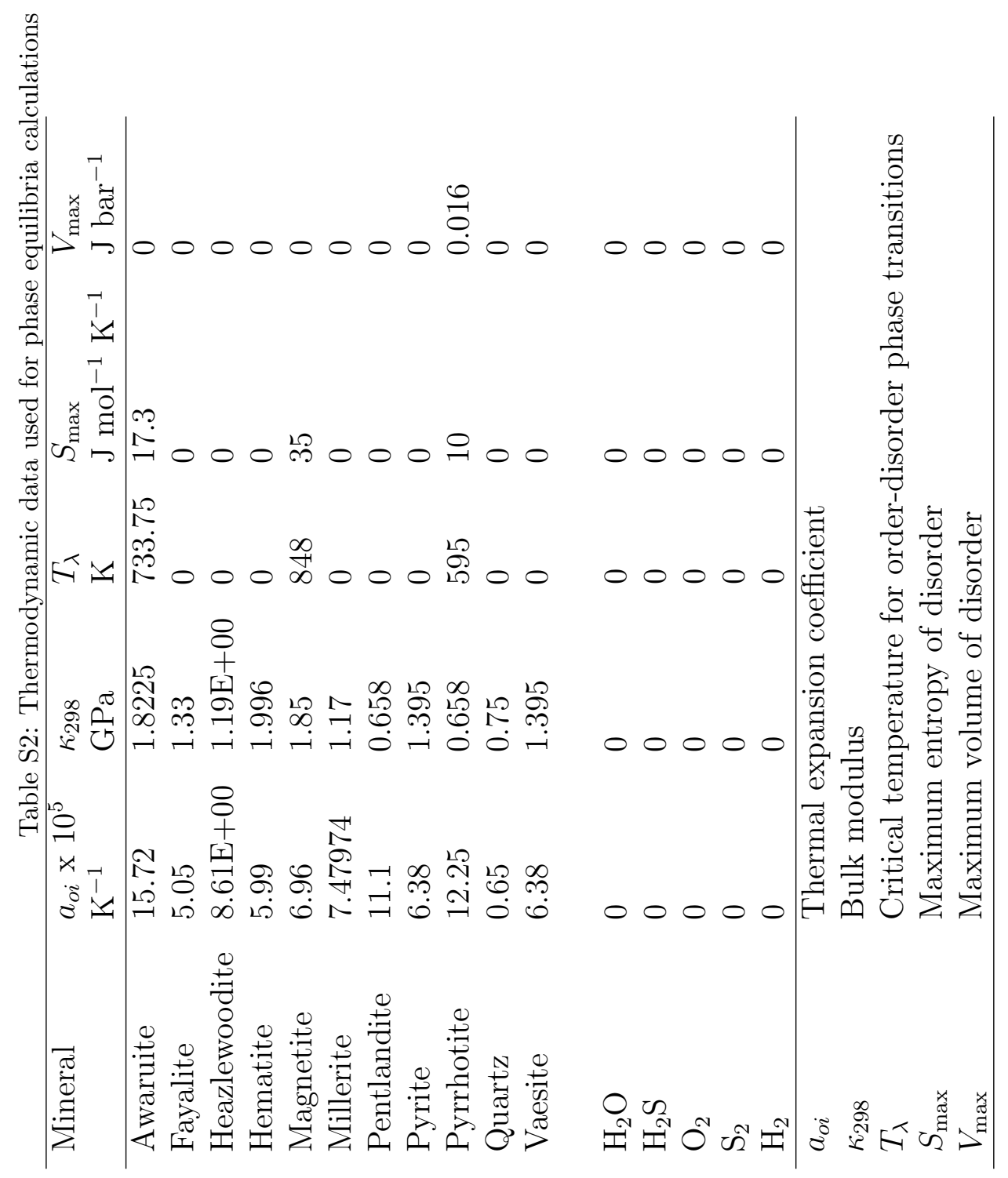

